University of New Hampshire

University of New Hampshire Scholars' Repository

$2-2005$

\title{
Nitrogen deposition onto the United States and Western Europe: A synthesis of observations and models.
}

\author{
Elisabeth A. Holland \\ NCAR \\ Rob Braswell \\ University of New Hampshire - Main Campus, rob.braswell@unh.edu \\ James Sulzman \\ NCAR \\ Jean-Francois Lamarque \\ NCAR
}

Follow this and additional works at: https://scholars.unh.edu/earthsci_facpub

\section{Recommended Citation}

Holland, E. A., Braswell, B. H., Sulzman, J. and Lamarque, J.-F. (2005), NITROGEN DEPOSITION ONTO THE UNITED STATES AND WESTERN EUROPE: SYNTHESIS OF OBSERVATIONS AND MODELS. Ecological Applications, 15: 38-57. doi:10.1890/03-5162

This Article is brought to you for free and open access by the Earth Sciences at University of New Hampshire Scholars' Repository. It has been accepted for inclusion in Earth Sciences Scholarship by an authorized administrator of University of New Hampshire Scholars' Repository. For more information, please contact Scholarly.Communication@unh.edu. 


\title{
NITROGEN DEPOSITION ONTO THE UNITED STATES AND WESTERN EUROPE: SYNTHESIS OF OBSERVATIONS AND MODELS
}

\author{
Elisabeth A. Holland, ${ }^{1,3}$ Bobby H. Braswell, ${ }^{2}$ James Sulzman, ${ }^{1,4}$ And Jean-Francois Lamarque ${ }^{1}$ \\ ${ }^{1}$ Atmospheric Chemistry Division, National Center for Atmospheric Research, P.O. Box 3000, \\ Boulder, Colorado 80305 USA \\ ${ }^{2}$ Institute for the Study of Earth, Oceans and Space, University of New Hampshire, Durham, New Hampshire 03824 USA
}

\begin{abstract}
The documented acceleration of $\mathrm{NH}_{3}$ and $\mathrm{NO}_{x}\left(\mathrm{NO}+\mathrm{NO}_{2}\right)$ emissions over the last 150 years has accelerated $\mathrm{N}$ deposition, compromising air and water quality and altering the functioning of terrestrial and aquatic ecosystems worldwide. To construct continental-scale $\mathrm{N}$ budgets, we produced maps of $\mathrm{N}$ deposition fluxes from site-network observations for the United States and Western Europe. Increases in the rates of $\mathrm{N}$ cycling for these two regions of the world are large, and they have undergone profound modification of biospheric-atmospheric $\mathrm{N}$ exchanges, and ecosystem function. The maps are necessarily restricted to the network measured quantities and consist of statistically interpolated fields of aqueous $\mathrm{NO}_{3}{ }^{-}$and $\mathrm{NH}_{4}{ }^{+}$, gaseous $\mathrm{HNO}_{3}$ and $\mathrm{NO}_{2}$ (in Europe), and particulate $\mathrm{NO}_{3}{ }^{-}$and $\mathrm{NH}_{4}{ }^{+}$. There remain a number of gaps in the budgets, including organic $\mathrm{N}$ and $\mathrm{NH}_{3}$ deposition. The interpolated spatially continuous fields allow estimation of regionally integrated budget terms. Dry-deposition fluxes were the most problematic because of low station density and uncertainties associated with exchange mechanisms. We estimated dry $\mathrm{N}$ deposition fluxes by multiplying interpolated surface-air concentrations for each chemical species by model-calculated, spatially explicit deposition velocities. Deposition of the oxidized $\mathrm{N}$ species, by-products of fossil-fuel combustion, dominate the U.S. N deposition budget with $2.5 \mathrm{Tg}$ of $\mathrm{NO}_{y}-\mathrm{N}$ out of a total of 3.7-4.5 $\mathrm{Tg}$ of $\mathrm{N}$ deposited annually onto the conterminous United States. Deposition of the reduced species, which are by-products of farming and animal husbandry, dominate the Western European N-deposition budget with a total of 4.3-6.3 Tg N deposited each year out of a total of 8.4-10.8 Tg N. Western Europe receives five times more $\mathrm{N}$ in precipitation than does the conterminous United States. Estimated N emissions exceed measured deposition in the United States by 5.37.81 Tg N, suggesting significant $\mathrm{N}$ export or under-sampling of urban influence. In Europe, estimated emissions better balance measured deposition, with an imbalance of between -0.63 and $2.88 \mathrm{Tg} \mathrm{N}$, suggesting that much of the $\mathrm{N}$ emitted in Europe is deposited there, with possible $\mathrm{N}$ import from the United States. The sampling network in Europe includes urban influences because of the greater population density of Western Europe. Our analysis of $\mathrm{N}$ deposition for both regions was limited by sampling density. The framework we present for quantification of patterns of $\mathrm{N}$ deposition provides a constraint on our understanding of continental biospheric-atmospheric $\mathrm{N}$ cycles. These spatially explicit wet and dry $\mathrm{N}$ fluxes also provide a tool for verifying regional and global models of atmospheric chemistry and transport, and they represent critical inputs into terrestrial models of biogeochemistry.
\end{abstract}

Key words: ammonium; atmospheric chemistry; biosphere-atmosphere $N$ exchange; dry deposition; $N$ deposition patterns; $N$ deposition, United States and Western Europe; Western Europe; $N O_{x}$; wet deposition.

\section{INTRODUCTION}

Increases in human population, fossil-fuel consumption, deforestation, and intensification of agriculture have altered the global nitrogen cycle, leading to an acceleration of emission and deposition of nitrogenous trace gases over the last century and a half

Manuscript received 20 May 2003; revised 1 March 2004; accepted 30 March 2004; final version received 2 May 2004. Corresponding Editor: W. L. Silver.

${ }^{3}$ E-mail: eholland@ucar.edu

${ }^{4}$ Present address: Oregon State University, Corvalis, Oregon 97331-4501 USA.
(Mayewski et al. 1990, Galloway et al. 1995, Matson et al. 1997, Smil 1997, Vitousek et al. 1997, Holland et al. 1999). More than 50\% of annual global reactive $\mathrm{N}$ emissions are generated directly or indirectly by human activities (Vitousek et al. 1997). This perturbation to the global $\mathrm{N}$ cycle is proportionally larger than the anthropogenic perturbation to the global carbon cycle (Schimel 1995). For short-lived gases like $\mathrm{NO}_{x}\left(\mathrm{NO}+\mathrm{NO}_{2}\right)$ and $\mathrm{NH}_{3}$, with tropospheric lifetimes of 1-5 days (Dentener and Crutzen 1994, Prather et al. 2001), increases in emissions lead to increased atmospheric concentrations and to deposition downwind of source regions, which decrease with distance 
from the source, until the gases and their reaction products are removed by precipitation or dry deposition to Earth's surface.

There is no global network of N-deposition measurements, and large terrestrial areas are unsampled, though global chemical model results and a limited number of network observations over land are available (Whelpdale and Kaiser 1997). Measurements of N deposition onto oceans are rare, with only a few longterm measurement stations (e.g., Bermuda, Whelpdale and Kaiser 1997, Whelpdale et al. 1997). Despite these observational limitations, the extant information clearly shows that increases in deposition have been greatest in developed regions of the Northern Hemisphere. Although substantial $\mathrm{NO}_{x}$ and $\mathrm{SO}_{2}$ emission increases in Asia and in the Tropics are projected due to expansion of industrialization, human population, and agriculture in developing countries (Galloway et al. 1994, Matthews 1994, Howarth et al. 1996, Lee et al. 1997, Vitousek et al. 1997, Whelpdale and Kaiser 1997, Whelpdale et al. 1997), we focus on deposition in two regions of the Northern Hemisphere (the continental United States and Western Europe), which have received chronic and increasing loads of $\mathrm{N}$ input since the Industrial Revolution (Mayewski et al. 1990, Holland et al. 1999).

The consequences of increased nitrogen deposition are profound and influence many aspects of the earth system, from human health to the sustainability of agriculture. The many adverse effects of $\mathrm{N}$ deposition and acidic precipitation on specific ecosystems are well documented for both American and European sites (Water, Soil and Air Pollution 85 [1995]; Global Biogeochemical Cycles 11 [1997]; Atmospheric Environment 34 [2000], 35 [2001], and 36 [2002] [all three are National Atmospheric Deposition special issues]; also see Church and Driscoll 1997, Grennfelt and Galloway 1997, Schulze 2000, Vitousek et al. 1997). Nitric acid, measured as aqueous $\mathrm{NO}_{3}^{-}$in wet-deposition measurements, is one of three acids comprising acid rain (the others are sulfuric and carbonic acid). Acid deposition, via the introduction of anions and $\mathrm{H}^{+}$, is associated with reductions in lake and soil $\mathrm{pH}$, and results in losses of soil nutrients and mobilization of potentially toxic cations (e.g., $\mathrm{Al}^{3+}$ ) (Schindler 1988, Hedin et al. 1994, Hedin and Likens 1996, Likens et al. 1996). Furthermore, high concentrations of tropospheric $\mathrm{NO}_{x}$ act as a principal catalytic precursor to tropospheric ozone (Liu et al. 1980, 1987, Albritton et al. 1994, Logan 1994), which is a strong oxidant and is known to damage living tissues and decrease plant production (Ollinger et al. 1997, Ollinger and Aber 2002). At the community scale, plant species shifts can be induced by $\mathrm{N}$ additions, leading to species-distribution change that often favor weeds over native plants, which in turn can reduce species diversity and change ecosystem function (Aerts et al. 1990, Berendse et al. 1992, Bob- bink et al. 1992, Sutton et al. 1993, Chapin et al. 1997, Hooper and Vitousek 1997, Tilman et al. 1997).

The impacts of $\mathrm{N}$ deposition on global carbon cycling are uncertain, but it is likely that some terrestrial ecosystems have been fertilized by the additional $\mathrm{N}$, and may currently be sequestering between $0.1-1.5 \mathrm{Pg}$ C per year globally (Peterson and Melillo 1985, Galloway et al. 1996, Townsend et al. 1996, Wedin and Tilman 1996, Holland et al. 1997, Jenkinson et al. 1999, Nadelhoffer et al. 1999a, $b$, Sievering 1999). For heavily impacted systems, however, sustained $\mathrm{C}$ sinks are unlikely (Schulze et al. 1989). Nitrogen-enhanced $\mathrm{CO}_{2}$ uptake by ecosystems will eventually be compromised by soil acidification and $\mathrm{O}_{3}$ pollution, and the other deleterious effects associated with $\mathrm{N}$ deposition.

Anthropogenic inputs of $\mathrm{N}$ have similar implications for the world's hydrologic systems. Large amounts of $\mathrm{N}$ introduced into coastal oceans and estuaries have resulted in widespread eutrophication and declining productivity of coastal marine fisheries (Howarth et al. 1996). Riverine inputs into the North Atlantic basin from Europe have increased by a factor of 3.5-10.6 relative to preindustrial inputs during the middle of the 1800s. Similarly, N fluxes into North American rivers have increased by a factor of 1.7-5.3, (Howarth et al. 1996). The potential for groundwater contamination is also high.

Developing mass-balance budgets of the important $\mathrm{N}$ species, which include surface exchange and atmospheric transport, is critical for a comprehensive understanding. Comparing estimates of $\mathrm{N}$ emissions to $\mathrm{N}$ deposition, where sufficient deposition data are available, provides an important check on estimates of emissions. Indeed, the fact that $\mathrm{N}$ can be emitted in one country and deposited in another is the cornerstone of the Transboundary Air Pollution agreement of the European Community and the Clean Air Act of the United States (Whelpdale et al. 1997). However, it is only recently that we have sufficient measurements to evaluate the implications of increasing $\mathrm{N}$ emissions at continental and global scales (Whelpdale et al. 1997).

Evaluation of the patterns of $\mathrm{N}$ deposition on regional scales requires estimation of spatially continuous fields from scattered point data. The associated estimates of uncertainty and some confidence that the extrapolation/interpolation procedure is statistically robust are also important. There has been a great deal of work in the development of techniques to apply to this area (Haas 1990, 1995, van Leeuwen et al. 1996, Lynch et al. 2000). Our work builds on the previous mapping work, and offers new perspectives: (1) the U.S. and European data are treated in as consistent a manner as possible for comparison, (2) it covers a longer time span than previous efforts (1978-1994), and (3) we construct $\mathrm{N}$ budgets by comparing estimated emissions and deposition, pointing out gaps in the measurements and our understanding. Our analysis is restricted to the measurements and sites participating in the U.S. and 
TABLE 1. Summary of measurements used in the analysis and mapping of $\mathrm{N}$ deposition, and the sources of data.

\begin{tabular}{lll}
\hline \hline & & Data source $\dagger$ \\
\cline { 2 - 3 } Measurement + & United States & Western Europe \\
\hline Wet deposition & & \\
$\mathrm{NH}_{4}{ }^{+}(\mathrm{aq})$ & NADP/NTN & EMEP \\
$\mathrm{NO}_{3}^{-}(\mathrm{aq})$ & NADP/NTN & EMEP \\
$\mathrm{DON}(\mathrm{aq})$ & not available & not available \\
$\mathrm{Ambient}$ air concentrations & & \\
$\mathrm{NH}_{3}(\mathrm{~g})$ & not available & not available \\
${\mathrm{Particulate} \mathrm{NH}_{4}{ }^{+}}_{\mathrm{HNO}_{3}(\mathrm{~g})}$ & NDDN/CASTNet & EMEP \\
${\mathrm{Particulate} \mathrm{NO}_{3}{ }^{-}}_{\mathrm{HNO}_{3}(\mathrm{~g})+\text { particulate } \mathrm{NO}_{3}{ }^{-}}$ & NDDN/CASTNet & too few measurements \\
$\mathrm{Organic}^{-}$nitrates & NDDN/CASTNet & too few measurements \\
\hline
\end{tabular}

$\dagger$ NADP/NTN $=$ National Atmospheric Deposition Program/National Trends Network; NDDN = National Dry Deposition Network; CASTNet = Clean Air Status and Trends Network; EMEP = European Monitoring and Evaluation Programme.

$\ddagger$ Key to abbreviations: aq, aqueous; g, gaseous.

Western European networks. Various species of inorganic-N deposition, organic-N deposition (Neff et al. 2002) and $\mathrm{NH}_{3}$ exchange (Atmospheric Environment 35 [2001]) have been measured, but these measurements are not inter-calibrated or inter-compared, nor are they compiled at a central location. Compilation of these hundreds and thousands of measurements is beyond the scope of this paper and of resources available for the analysis. We hope that the framework we present lays out sufficient justification for such a compilation with full participation of the scientific community led by an international scientific organization, i.e., World Meteorological Organization (WMO), United Nations Environmental Programme (UNEP), and/or Scientific Council on Problems of the Environment (SCOPE). The data used in this analysis, including standardization, quality control, and spatial maps, are archived and publicly available online. ${ }^{5}$

\section{Data And Methods}

We compiled observations from monitoring networks in the United States and Europe, in order to construct $0.5 \times 0.5$ degree resolution maps of $\mathrm{N}$ deposition by species (Table 1). In the United States, wetdeposition data were provided by the National Atmospheric Deposition Program/National Trends Network (NADP/NTN, 1996, 2001, Lamb and Bowersox 2000). Measurements of ambient air concentrations, used to calculate dry-deposition fluxes, were provided by the National Dry Deposition Network (NDDN) and the Clean Air Status and Trends Network (CASTNet) (Fig. 1; Edgerton et al. 1992). In Europe, measurements of wet-deposition fluxes of $\mathrm{NO}_{3}{ }^{-}$and $\mathrm{NH}_{4}{ }^{+}$and ambient air concentrations of $\mathrm{HNO}_{3}, \mathrm{NO}_{2}$, particulate $\mathrm{NO}_{3}{ }^{-}$, and particulate $\mathrm{NH}_{4}{ }^{+}$were provided by the Cooperative Programme for Monitoring and Evaluation of the LongRange Transmission of Air Pollutants in Europe (European Monitoring and Evaluation Programme, EMEP).

${ }^{5}\langle$ http://www.daac.ornl.gov $\rangle$
Both the U.S. and European measurements span the 1978-1994 time period with some sites beginning later than others.

\section{Wet-deposition measurements}

At the NADP/NTN sites within the United States, precipitation is accumulated in buckets that are triggered to open at the onset of rain. Samples from precipitation buckets are gathered weekly at sites throughout the United States (Fig. 1) and are sent to a central laboratory for chemical analyses. The chemical analyses include measurement of concentrations of hydrogen ions $\left(\mathrm{H}^{+}\right)$, associated anions $\left(\mathrm{SO}_{4}{ }^{2-}, \mathrm{NO}_{3}{ }^{-}, \mathrm{Cl}^{-}\right)$,

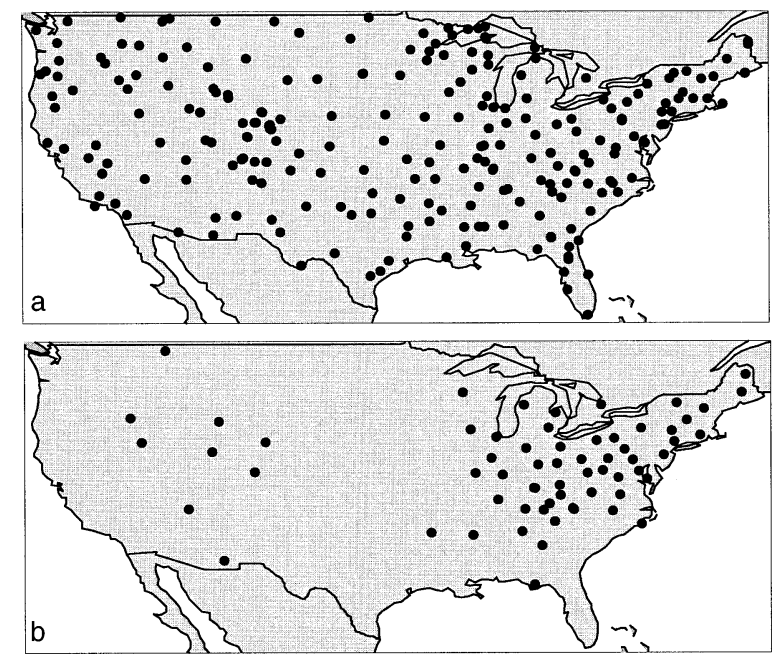

FIG. 1. Measurement sites for each of the U.S. networks considered: (a) wet-deposition measurements of $\mathrm{NH}_{4}{ }^{+}$and $\mathrm{NO}_{3}{ }^{-}$from the NADP/NTN network with 237 sites, spanning the years 1978-1994 (site information available online: $\langle$ http://nadp.sws.uiuc.edu//); (b) ambient concentration measurements of $\mathrm{HNO}_{3}$ and particulate $\mathrm{NO}_{3}{ }^{-}$and $\mathrm{NH}_{4}{ }^{+}$from the NDDN/CASTNet network with 65 sites spanning the years 1988-1995 (site information available online: 〈http://www. epa.gov/castnet)). 
and base cations $\left(\mathrm{NH}_{4}^{+}, \mathrm{Ca}^{2+}, \mathrm{Mg}^{2+}, \mathrm{K}^{+}\right.$, and $\left.\mathrm{Na}^{+}\right)$. Quality control is also checked by evaluation of the charge balance of the samples. In Europe, the method of sampling varied from location to location, country to country, and, in general, differed from the method used in the United States. In Europe, samples of precipitation were collected daily using either the precipitation-only samplers (described above) or bulk sampling devices that are continually open to the atmosphere, and are thus more subject to contamination (Erisman et al. 1994, van Leeuwen et al. 1995, 1996, Hjellbrekke et al. 1997). Chemical sampling and analyses were usually done on a country-by-country basis and inter-laboratory tests were conducted annually (Dovland and Pedersen 1997). Some of the sites collected data monthly rather than daily (Lazaropole, former-Yugoslovia; Neuglobsow, Germany; Jarczew, Poland; Rarau, Seminic, Paring, Fundata, Turia, and Masun, Romania; and Ivan Sedlo, Bosnia-Herzogovina). These data were the only available observations for large areas and so we included them in our analysis despite the potential problems associated with monthly sampling. The European data were published as "Data report 1995" (Hjellbrekke et al. 1997).

The wet-deposition data were averaged annually for each measurement site. For the United States, annual means were acquired directly from the NADP/NTN. For the European EMEP data sets, we followed the same quality-assurance plan used by NADP to ensure comparability. The quality-assurance criteria required in order to include a site for a year are the following: (1) There must be valid samples for at least $75 \%$ of the summary period. (2) For at least $90 \%$ of each month, there must be precipitation data either from the rain gauge or from the sample volume. (3) There must be valid samples for at least $75 \%$ of the total precipitation reported for the summary period. (4) For the entire summary period the total precipitation as measured for the sample volume must be at least $75 \%$ of the total precipitation measured by the rain gauge for all valid samples where both values are available. Criterion 4 does not pertain to the EMEP data set, because data from a separate rain collector were not reported. In the United States, the number of sites that met the completeness criteria varied between 21 and 203 with a mean of 156 sites over the time period. The number of sites was smallest as the network was starting in the late 1970s, and largest between 1985 and 1994, when the number of sites rose to $\sim 200$. Across Europe, data from 113 out of 188 sites satisfied the completeness criteria. There were 18 sites at the beginning of the monitoring period, growing to 50-75 participating sites during 1986-1994, with a mean of 50 sites in any given year.

For both the United States and Europe, wet deposition was calculated as follows:

$$
C_{\mathrm{w}}=\frac{\sum_{i=1}^{n}\left(C_{i} P_{i}\right)}{\sum_{i=1}^{n}\left(P_{i}\right)}
$$

where $C_{\mathrm{w}}$ is the precipitation-weighted mean concentration in units of milligrams per liter, calculated from the $n$ valid samples for the season. (Each individual valid sample concentration $C_{i}$ is weighted by the individual precipitation amount $P_{i}$ for the sample. This calculation makes the assumption that the chemistry of the invalid samples is represented by the chemistry of the valid samples for that summary period:

$$
F_{\text {wet }}=C_{\mathrm{w}} P_{\mathrm{t}}
$$

where $F_{\text {wet }}$ is the wet-deposition flux (in nanomoles per liter), and $P_{\mathrm{t}}$, (in millimeters of $\mathrm{H}_{2} \mathrm{O}$ ) is the total precipitation over the averaging time period (i.e., (mmoles $\times$ molecular weight $/ \mathrm{L} \times \mathrm{mm}$ precipitation $) / 100=\mathrm{kg}$ / ha).

\section{Dry-deposition measurements}

For both regions, dry-deposition fluxes were calculated by multiplying the mapped ambient air concentration of the chemical species by a calculated mapped deposition velocity. In the United States, atmospheric concentrations of trace species were measured by pumping ambient air through a filter pack containing three filters: a Teflon filter for dry deposition of aerosols (particulate $\mathrm{NO}_{3}{ }^{-}$and $\mathrm{NH}_{4}{ }^{+}$), a nylon filter for collection of gaseous $\mathrm{HNO}_{3}$, and dual potassium carbonateimpregnated cellulose filters for collection of $\mathrm{SO}_{2}$ (Edgerton et al. 1992). The filter packs were changed weekly, and filter extracts were analyzed in a central laboratory within $72 \mathrm{~h}$ of filter extraction. Similarly, in Europe the atmospheric concentrations of trace species were made by pumping ambient air through a filter pack (Hjellbrekke et al. 1997). However, the filters and flow rates varied from country to country. For example, in Italy, particulate ammonium was sampled using a Teflon filter (Gelman Zeflour, with a 1 micron pore size) with a flow rate of $17 \cdot \mathrm{m}^{3} \cdot \mathrm{d}^{-1}$. In Hungary, particulate ammonium was sampled using a Teflon filter (Kipzer Paraplan) with a flow rate of $25 \cdot \mathrm{m}^{3} \cdot \mathrm{d}^{-1}$. There were similar contrasts for gas sampling. For example, in Italy $\mathrm{NO}_{2}$ concentrations were measured by a chemi-luminescence technique, while in Hungary $\mathrm{NO}_{2}$ was measured using a Triethanolamine solution with a $0.5 \mathrm{~m}^{3} /$ $\mathrm{d}$ flow rate. The measurement techniques are summarized in the EMEP data report (Hjellbrekke et al. 1997: 43-46 [Tables 1.1-1.3]). In addition, there was yearto-year variation in the measurement techniques. Hicks et al. (1991) compare various approaches and review the associated problems.

Neither the European nor the U.S. dry-deposition measurements spanned the whole 1978-1994 time period. In the United States, some sites began measurements in 1989 with additional sites added in 1990 for 
TABle 2. Pairing of DeFries and Townsend (1995) vegetation classes to the vegetation classes set up by Weseley (1988, 1989) for deposition velocity calculations.

\begin{tabular}{|c|c|c|c|}
\hline \multicolumn{2}{|r|}{ Weseley } & \multicolumn{2}{|c|}{ DeFries and Townsend } \\
\hline Type & Description & Description & Type \\
\hline 1 & urban land/almost no vegetation & & $\ldots$ \\
\hline 2 & agricultural land, usually well watered & croplands & 11 \\
\hline 3 & rangeland, usually with low soil & grasses & 10 \\
\hline 4 & deciduous forest & $\begin{array}{l}\text { evergreen broadleaf forest } \\
\text { deciduous forest } \\
\text { woodlands }\end{array}$ & $\begin{array}{l}2 \\
4 \\
6\end{array}$ \\
\hline 5 & coniferous forest & $\begin{array}{l}\text { evergreen needleleaf forest } \\
\text { deciduous needleleaf forest }\end{array}$ & $\begin{array}{l}1 \\
3\end{array}$ \\
\hline 6 & mixed forests, including wetland & mixed forests & 5 \\
\hline 7 & water, salt and freshwater & oceans & 0 \\
\hline 8 & barren land, mostly desert & bare & 12 \\
\hline 9 & non-forested woodland & & $\ldots$ \\
\hline 10 & mixed agricultural and rangeland & & $\cdots$ \\
\hline \multirow[t]{4}{*}{11} & $\begin{array}{l}\text { rocky open areas occupied by low-growing } \\
\text { shrubs }\end{array}$ & wooded grasslands/shrubs & 7 \\
\hline & & closed brushlands or shrublands & 8 \\
\hline & & open shrublands & 9 \\
\hline & & mosses and lichens & 13 \\
\hline
\end{tabular}

a total of 65 sites. In Europe, the number of sites varied with the chemical species considered: 33 sites sampled gaseous $\mathrm{HNO}_{3}$ and particulate $\mathrm{NO}_{3}^{-}, 39$ sites sampled particulate $\mathrm{NH}_{4}{ }^{+}$, and 50 sites sampled gaseous $\mathrm{NO}_{2}$. For both the United States and Europe we used the available data to calculate monthly average concentrations, averaging over the time span of available measurements and taking into account the differences in sampling frequency.

We calculated the deposition velocity in a way that was consistent for both the United States and Europe, estimating surface exchanges of chemical species based on the resistance approach developed by Weseley (1989). The dry-deposition flux, $F_{\text {dry }}$ (molecules per square meter per second) was calculated as the product of deposition velocity, $V_{\mathrm{d}}$, (meters per second) and concentration, $\mathrm{C}_{\mathrm{n}}$ (molecules per meter cubed),

$$
F_{\text {dry }}=V_{\mathrm{d}} \mathrm{C}_{\mathrm{n}}
$$

and the deposition velocity was assumed to be inversely proportional to the sum of three resistances,

$$
V_{\mathrm{d}}=\left(r_{\mathrm{a}}+r_{\mathrm{b}}+r_{\mathrm{c}}\right)^{-1}
$$

where $r_{\mathrm{a}}$ is the aerodynamic resistance, $r_{\mathrm{b}}$ the resistance of the laminar sub-layer between the surface and the turbulent boundary layer, which depends on the diffusivity of the species, and $r_{\mathrm{c}}$ the bulk surface resistance that depends on land surface characteristics and on the solubility and reactivity of the chemical species. In general, $r_{\mathrm{b}}$ is small, and $r_{\mathrm{a}}$ and $r_{\mathrm{c}}$ depend on a variety of parameters, which in turn depend on both the land cover and the chemical species considered. For particulate fluxes, we assumed that the relevant particles had a diameter between 0.1 and $1 \mu \mathrm{m}$ (Wyers and Duyzer 1997), and applied the $u^{*}$ parameterizations suggested by Weseley et al. (1985) and Erisman and Draaijers (1995).

The $V_{\mathrm{d}}$ calculation requires maps of meteorological variables and land cover. Site-specific meteorological data were not available for many of the European sites. Therefore we used model results from the NCAR/ NCEP reanalyses (Kalnay et al. 1996) to provide a regionally consistent and spatially explicit data set containing the meteorological information necessary to compute deposition velocities: pressure, temperature, wind, and precipitation.

To assign land cover classes, we used the $8-\mathrm{km}$ resolution land cover map of Defries and Townsend (1995), spatially re-aggregated to $0.5 \times 0.5$ degrees, in order to assign land-cover classes. Implementation of the resistance model (which has its own land surface types) was accomplished by matching the Weseley (1998, 1989) land-cover classes to the DeFries and Townsend (1995) classes (Table 2). To match the relatively high resolution of the land-cover data, the meteorological data were also interpolated from their original resolution ( $\mathrm{T} 42$ or $\sim 2.8^{\circ}$ ("T42" = an equally spaced grid overlaid on the earth's surface consisting of 128 cells of longitude and 64 cells of latitude; spacing is $\sim 2.8^{\circ}$ longitude $\times 2.8^{\circ}$ latitude) ) to $0.5 \times 0.5^{\circ}$ resolution. All $V_{\mathrm{d}}$ output was mapped at $0.5 \times 0.5^{\circ}$ resolution globally. Finally, dry-deposition fluxes were mapped by statistically interpolating the ambient concentrations of each chemical species and then multiplying the interpolated concentrations by the calculated deposition velocities for each $0.5^{\circ}$ grid cell.

Critical evaluation of the initial $V_{\mathrm{d}}$ maps for the United States and Europe uncovered a problem introduced by the mismatch in spatial resolution of the land cover map $(8 \times 8 \mathrm{~km})$ and the meteorological data $(2.5 \times$ 
$\left.2.5^{\circ}\right)$. The high wind speed modeled over the oceans introduced spuriously high deposition velocities for some of the coastal grid cells because the meteorological data were produced on a much larger grid than the land-cover data. The actual $V_{\mathrm{d}}$ calculations were done in an intermediate grid size $\left(0.5 \times 0.5^{\circ}\right)$ to try to reduce the problems associated with the spatial mismatch, but did not solve the problem entirely. The deposition velocities calculated on land with the high ocean wind speeds were excluded from our calculations by generating a cell-masking routine. The average deposition velocity of surrounding grid cells with the same vegetation type was re-substituted to complete the maps of $V_{\mathrm{d}}$. The problem underscores the difficulty and importance of careful spatial analysis.

Deposition of aerosols on forests differs from deposition onto low-stature vegetation (Jonas and Heinemann 1995, Weseley and Hicks 1999). A physically based parameterization distinguishing the two classes would be ideal but is problematic for a one-dimensional model because of sub-grid-scale horizontal heterogeneity. Therefore we relied on the empirical derivation of Weseley (1989) to calculate the deposition velocities for particulate $\mathrm{NO}_{3}{ }^{-}$and $\mathrm{NH}_{4}{ }^{+}$. To further examine the sensitivities of the calculation, we revised the model to include the influence of forest type as described by Jonas and Heinemann (1995):

$$
V_{\mathrm{d}, i}=\varepsilon V_{\mathrm{d}, \mathrm{ref}}
$$

where $V_{\mathrm{d}, \text { ref }}$ is the deposition velocity of the "reference forest type," $\varepsilon$ is a multiplying factor, and $V_{\mathrm{d}, i}$ represents the modeled $V_{\mathrm{d}}$ for individual forest types in the domain. The multiplying factor was calculated as the mean of the factors calculated for all of the forest types sampled, to yield 6.71 for deciduous forests and 10.4 for evergreen forests, the only vegetation types to which we applied Eq. 5.

A further complication was introduced by the fact that in Europe, $\mathrm{HNO}_{3}$ (gaseous, g) and particulate $\mathrm{NO}_{3}^{-}$ were combined and reported as a single value by EMEP. It was impossible to partition out the sums into their individual components based on the available data. Thus, for the sum of $\mathrm{HNO}_{3}(\mathrm{~g})$ plus particulate $\mathrm{NO}_{3}{ }^{-}$, we calculated two dry-deposition fluxes as a means of bracketing the estimate: one as if the flux were made up entirely of particulate $\mathrm{NO}_{3}{ }^{-}$and another as if the flux were made up entirely of the $\mathrm{HNO}_{3}(\mathrm{~g})$. This necessarily introduces an additional uncertainty because the deposition velocities of the $\mathrm{HNO}_{3}(\mathrm{~g})$ and particulate $\mathrm{NO}_{3}{ }^{-}$differ by as much as five-fold.

\section{Statistical treatment}

To create the interpolated fields of wet-deposition flux and dry-species concentrations, we used a variant of a standard geostatistical method, the moving-window residual-Kriging (MWRK) algorithm developed by Haas $(1990,1995)$. This analysis/interpolation tool was developed originally for use with atmospheric- deposition network data. Kriging is a statistical method of providing unbiased estimates of variables in regions where the available data exhibit spatial autocorrelation, and "Kriging estimates" are obtained in such a way that they have minimum variance (Cressie 1991). In the Haas (1995) algorithm, a moving window is used to isolate subregions of the data for calculation of variograms, which is critical because the distribution of deposition at the continental scale is typically not normal. This Kriging application also allows the application of prior information (covariates) that are correlated with the data of interest and available at all grid-cell locations.

We found the MWRK method to be a satisfying alternative to other interpolation methods (e.g., cubic splines, bilinear/nearest neighbor approaches) for several reasons: (1) It allows the use of spatial covariates such as precipitation and elevation. (2) It allows temporal correlations in the data to be included in the local model. (3) It provides estimates of uncertainty via cross-validations (site-by-site removal) and by including confidence intervals for the estimates (based upon Kriging variance). The uncertainty estimates also provide a means to evaluate the importance of the inclusion of spatial covariates, and the value of including the temporal correlation in the spatial estimate. The spatial-temporal aspect of the analysis also allows examination of regionally integrated trends using simple regression techniques, thereby avoiding the need for multi-layer hypothesis testing (e.g., Stoddard 1994, Stoddard et al. 1998), which is a common approach.

Kriging of the wet-deposition measurements and the dry-deposition measurements were handled somewhat differently. Spatial interpolation of the annual mean site observations of wet deposition of $\mathrm{NO}_{3}{ }^{-}$and $\mathrm{NH}_{4}{ }^{+}$ were performed using moving-window (no time dimension) Kriging (Haas 1990) with precipitation and elevation covariates. The analysis was performed using 237 sites for the wet-deposition estimates within the United States, and 115 sites for the wet-deposition estimates within Europe (Figs. 1 and 2). Data from three European sites were excluded from the Kriging analysis because they contained questionably high deposition values: Lesogorrsky, Russia; Stina de Vale, Romania; and Ispra, Italy.

The choice of precipitation and elevation as covariates was made after evaluating the effects of a wide range of variables (e.g., temperature, humidity) on Kriging model statistics. These statistics were based on a series of cross-validation studies where each site (in turn) is withheld from the analysis, and the distribution of residuals (modeled minus predicted deposition) is examined (Table 1, Fig. 3). For the United States, we used gridded precipitation and elevation information from the VEMAP Phase I data set (Kittel et al. 1995). For Europe, we used the Leemans and Cramer (1991) global data set. All covariates and our desired output base map for both regions are defined as 

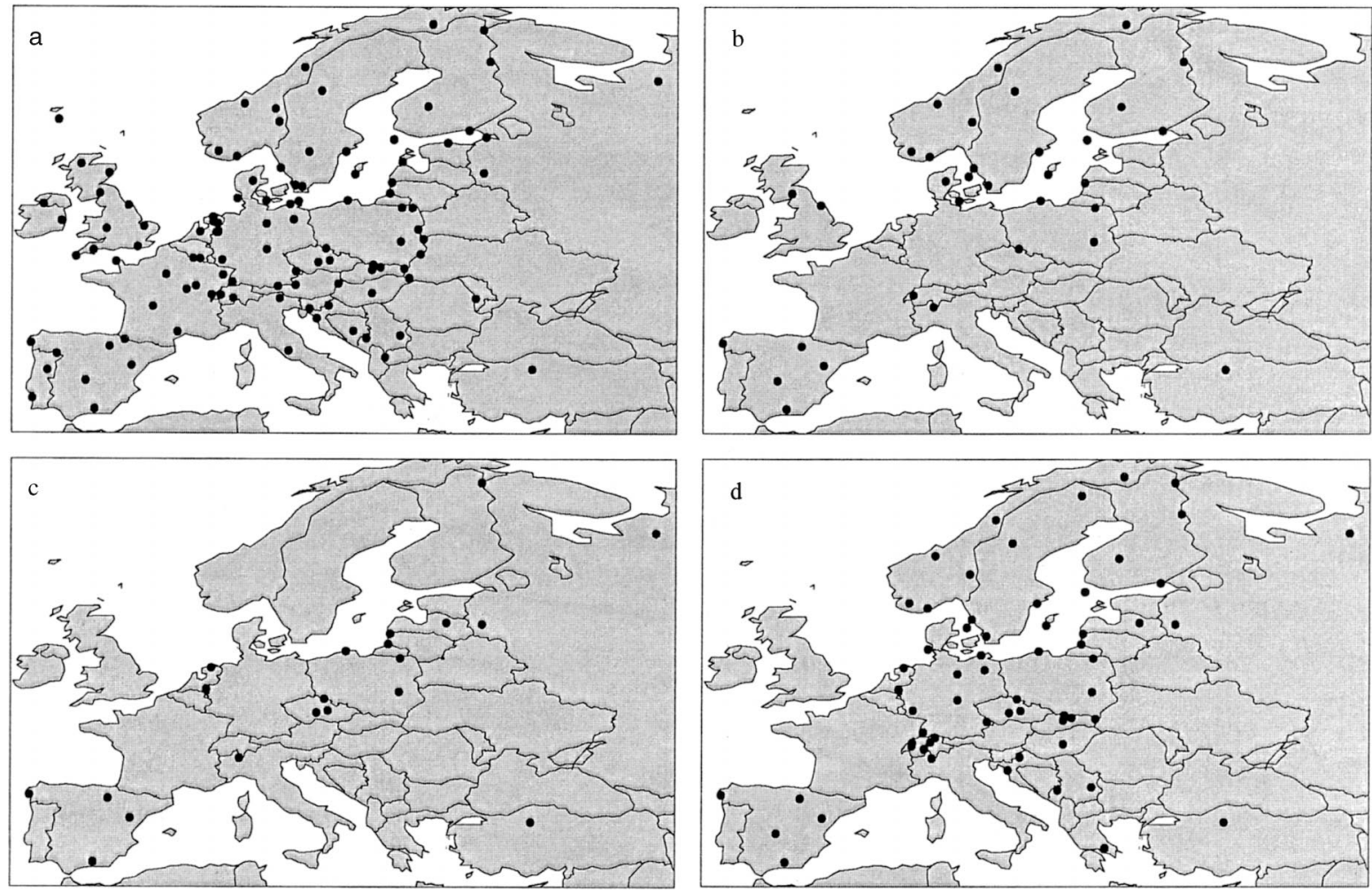

FIG. 2. Measurements sites for the European deposition measurements from the EMEP network spanning the years 19781994 (site information available online: 〈http://emep.int)): (a) wet-deposition measurements of $\mathrm{NH}_{4}{ }^{+}$and $\mathrm{NO}_{3}{ }^{-}$with 106 sites meeting the completeness criteria described in Data and Methods and spanning the years 1978-1994; (b) ambient-concentration measurements of $\mathrm{HNO}_{3}$ (gaseous, g) plus particulate $\mathrm{NO}_{3}{ }^{-}$with 33 sites; (c) ambient-concentration measurements of particulate $\mathrm{NH}_{4}{ }^{+}$with 21 sites; (d) ambient-concentration measurements of $\mathrm{NO}_{2}$ with 61 sites.

before on a $0.5^{\circ} \times 0.5^{\circ}$ grid (see Dry-deposition measurements; see also Figs. 4 and 5).

Kriging of the ambient concentrations of dry species $\left(\mathrm{HNO}_{3}, \mathrm{NO}_{2}\right.$, particulate $\mathrm{NH}_{4}{ }^{+}$, particulate $\mathrm{NO}_{3}, \mathrm{HNO}_{3}$ plus particulate $\mathrm{NO}_{3}{ }^{-}$, and particulate $\mathrm{NH}_{4}{ }^{+}$plus $\mathrm{NH}_{3}$ ) was performed using a modification of the MWRK called "moving-cylinder residual Kriging" (Haas 1995). This approach extends the circular spatial window along the time axis to form a cylinder. The time dimension is included in order to exploit the existence of temporal correlations in the observations (Haas 1995), which are significant in the dry-species concentrations. This approach is based on the addition of temporal variograms in the Kriging estimation. Crossvalidation analysis yielded a "cylinder length" of three months so that an estimate at time $t$ used information (observations) from times $t-1$ (month) and $t+1$ month. In Europe, the dry-deposition data lacked the temporal coherence needed to defend application of the moving-cylinder residual-Kriging technique. Thus, Kriging of the ambient concentrations of $\mathrm{NO}_{2}, \mathrm{HNO}_{3}$ and particulate $\mathrm{NO}_{3}{ }^{-}$, and particulate $\mathrm{NH}_{4}{ }^{+}$were done using the MWRK with no covariates.

\section{RESUlts AND Discussion}

The magnitude and spatial patterns of the interpolated, annual-mean nitrogen-deposition fluxes differ significantly by species and by region (Figs. 4 and 5). These characteristic differences arise from the geography of emission of the various sources gases, the atmospheric lifetimes and properties of the chemical species involved from emission to deposition, and the strength of atmospheric transport. In addition, the spatial patterns of wet deposition, gaseous dry deposition, and particulate/aerosol dry deposition generally differ because the physical deposition processes themselves are so different.

The spatial distributions of $\mathrm{NO}_{y}-$ and $\mathrm{NH}_{x}$-deposition fluxes are generally distinct from one another because their sources $\left(\mathrm{NO}_{x}\right.$ and $\left.\mathrm{NH}_{3}\right)$ are distributed differently. The primary sources of $\mathrm{NO}_{x}$ are fossil-fuel combustion (40-58\%), followed by soils (13-20\%), lightning (8$17 \%)$, biomass burning (12-17\%), photochemical oxidation of $\mathrm{NH}_{3}(5-8 \%)$, aircraft $(1 \%)$, and transport from the stratosphere $(0.2-0.3 \%)$, though continental proportions may differ from these global proportions. The release of $\mathrm{NH}_{3}$ to the atmosphere is a result of both agricultural activities and natural sources. Contributions to atmospheric $\mathrm{NH}_{3}$ include animal husbandry (49-63\%), fertilizer application (11-12\%), oceanic emissions (14-17\%), soil emissions (10-13\%), biomass burning (4-7\%), human excrement (5-8\%), and 
coal combustion and automobiles (3-4\%) (Holland et al. 1999, Prather et al. 2001).

\section{Wet-deposition fluxes}

In the United States the patterns of wet deposition of $\mathrm{NH}_{4}{ }^{+}$and $\mathrm{NO}_{3}{ }^{-}$differed significantly from one another in both distribution and intensity (Figs. 4a and b). In the conterminous United States, $\mathrm{NH}_{4}{ }^{+}$wet deposition was greatest over the upper Midwest with a broad feature of high wet deposition values (Fig. 4a). Peak wet-deposition $\mathrm{NH}_{4}{ }^{+}$fluxes were greater than 3.27 $\mathrm{kg} \mathrm{N} / \mathrm{ha}$, with an average wet-deposition flux of 1.38 $\mathrm{kg} \mathrm{N} /$ ha over the continent (Fig. 4a). By contrast, $\mathrm{NO}_{3}{ }^{-}$ wet deposition was greatest over the Northeastern United States, with peak values of $>5 \mathrm{~kg} \mathrm{~N} / \mathrm{ha}$, but with an average deposition flux of $1.64 \mathrm{~kg} \mathrm{~N} / \mathrm{ha}$ (Fig. 4b). The $\mathrm{NO}_{3}{ }^{-}$fluxes in the highest quartile covered a smaller area than the $\mathrm{NH}_{4}{ }^{+}$fluxes in the highest quartile. Overall the wet deposition flux of $\mathrm{NO}_{3}{ }^{-}$slightly exceeded that of $\mathrm{NH}_{4}^{+}$with 1.28 and $1.08 \mathrm{Tg} \mathrm{N}$, respectively, deposited onto the conterminous United States.

In Europe the spatial patterns of wet deposition of $\mathrm{NH}_{4}^{+}$and $\mathrm{NO}_{3}{ }^{-}$were similar but the intensity of $\mathrm{NH}_{4}{ }^{+}$ and $\mathrm{NO}_{3}{ }^{-}$deposition differed even more than for the United States (Figs. 5a and b). Peak $\mathrm{NH}_{4}{ }^{+}$wet-deposition fluxes of $>17 \mathrm{~kg} \mathrm{~N} / \mathrm{ha}$ were centered over eastern Europe, but fluxes $>6 \mathrm{~kg} \mathrm{~N} / \mathrm{ha}$ were widespread throughout Eastern and Central Europe (Fig. 5a). The peak European fluxes were much greater than the peak U.S. fluxes. Across Europe the average $\mathrm{NH}_{4}{ }^{+}$deposition fluxes were $4.2 \mathrm{~kg} \mathrm{~N} / \mathrm{ha}$, more than twice the U.S. average. Nitrate wet-deposition fluxes peaked at $>8 \mathrm{~kg}$ N/ha over Central Europe with average wet-deposition fluxes of $2.56 \mathrm{~kg} \mathrm{~N} / \mathrm{ha}$ over the European continent, much larger than the U.S. average $\mathrm{NO}_{3}{ }^{-}$deposition fluxes (Fig. 5b). Over both continents the wet-deposition fluxes were broadly positively correlated with precipitation. Inclusion of precipitation as a covariate significantly reduced the uncertainty associated with the Kriging extrapolation of the wet deposition. Both $\mathrm{NH}_{4}{ }^{+}$and $\mathrm{NO}_{3}{ }^{-}$wet-deposition fluxes were greater and the regions of high deposition more extensive over Europe than the conterminus United States.

\section{Dry-deposition fluxes}

In the United States, only three chemical species were measured as part of the dry-deposition network: nitric acid $\left(\mathrm{HNO}_{3}\right.$ [gaseous, g]), particulate nitrate $\left(\mathrm{NO}_{3}^{-}\right)$, and particulate ammonium $\left(\mathrm{NH}_{4}^{+}\right)$. Over the United States the gas-phase $\mathrm{HNO}_{3}$ deposition was the largest flux, with peak-deposition fluxes of $>5.7 \mathrm{~kg}$ $\mathrm{N} \cdot \mathrm{ha}^{-1} \cdot \mathrm{y}^{-1}$, and a continental average flux of $1.35 \mathrm{~kg}$ $\mathrm{N} \cdot \mathrm{ha}^{-1} \cdot \mathrm{y}^{-1}$ (Fig. 4d). Particulate $\mathrm{NO}_{3}^{-}$fluxes were substantial over the upper Midwest, with peak fluxes of $>1.85 \mathrm{~kg} \mathrm{~N} \cdot \mathrm{ha}^{-1} \cdot \mathrm{y}^{-1}$ covering a limited area, but the continental average particulate $\mathrm{NO}_{3}{ }^{-}$flux was an order of magnitude smaller at $0.18 \mathrm{~kg} \mathrm{~N} \cdot \mathrm{ha}^{-1} \cdot \mathrm{y}^{-1}$ (Fig. 4e). Peak particulate $\mathrm{NH}_{4}{ }^{+}$fluxes of $0.76 \mathrm{~kg} \mathrm{~N} \cdot \mathrm{ha}^{-1} \cdot \mathrm{y}^{-1}$ were
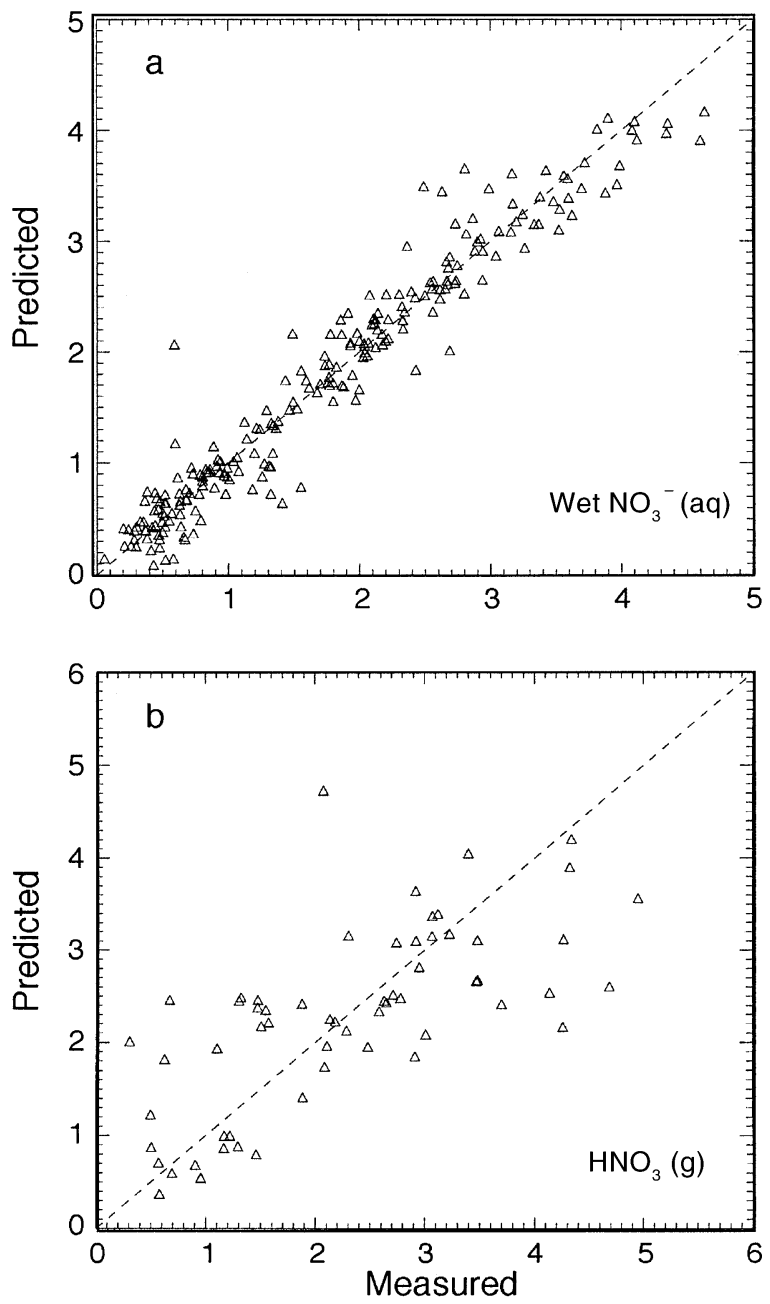

FIG. 3. Cross-validation produced from the Kriging interpolation for the United States; the units are $\mathrm{kg} \mathrm{N} \cdot \mathrm{ha}^{-1} \cdot \mathrm{y}^{-1}$ : (a) wet-deposition flux of $\mathrm{NO}_{3}{ }^{-}$based on 237 NADP sites, $r^{2}=0.93$; (b) dry-deposition flux of gaseous $\mathrm{HNO}_{3}$ based on 60 NDDN sites, $r^{2}=0.48$. These correlations were produced by removing a single site from the interpolation and estimating the value for that site based on all of the other surrounding sites. The predicted value is then compared to the value measured at that site.

much smaller than peak $\mathrm{NO}_{3}{ }^{-}$fluxes (Figs. 4c and e). However, the extensive spatial coverage of high particulate ammonium fluxes translated into a slightly higher continental average of $0.23 \mathrm{~kg} \mathrm{~N} \cdot \mathrm{ha}^{-1} \cdot \mathrm{y}^{-1}$. The highest particulate $\mathrm{NO}_{3}{ }^{-}$fluxes overlaid the areas with the highest $\mathrm{NH}_{4}{ }^{+}$fluxes, arguing for deposition as ammonium nitrate. For the United States, the dry deposition of oxidized nitrogen dominated the measured dry-deposition budgets (Table 5). Ammonia, $\mathrm{NO}_{2}(\mathrm{~g})$, and oxidized and reduced organic-N exchange were not sampled by the networks and are not included in the analysis but may be important contributors to the overall $\mathrm{N}$ budgets (Langford et al. 1992, Lerdau et al. 2000, Neff et al. 2002). 

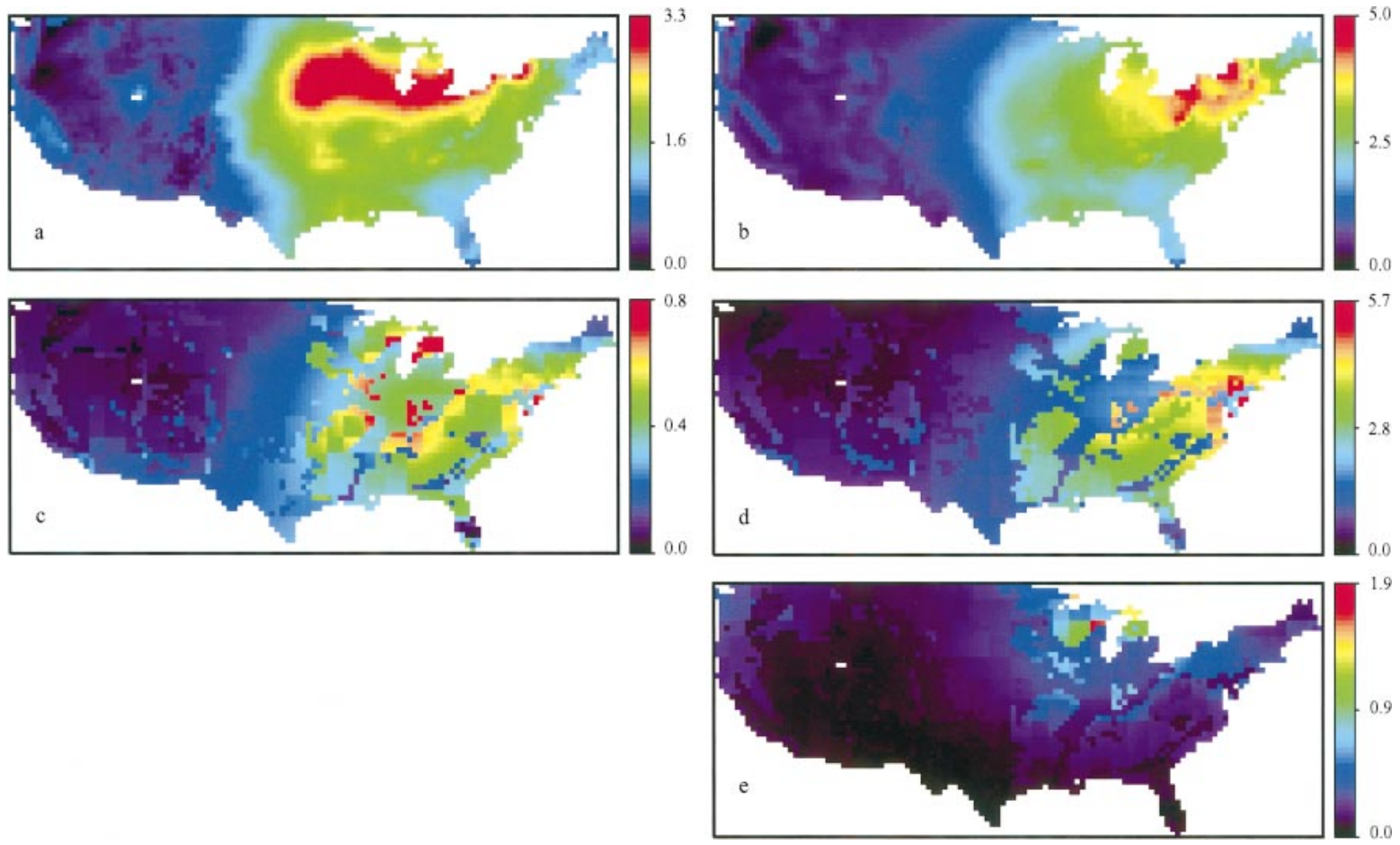

FIG. 4. Spatial distribution of the $\mathrm{N}$ deposition flux estimated for each of the individual $\mathrm{N}$ species measured (kg N/ha) for the conterminous United States: (a) wet-deposition flux of $\mathrm{NH}_{4}{ }^{+}$(aq); (b) wet-deposition flux of $\mathrm{NO}_{3}^{-}$(aq); (c) drydeposition flux of particulate $\mathrm{NH}_{4}{ }^{+}$; (d) dry-deposition flux of gaseous $\mathrm{HNO}_{3}\left(\mathrm{~g}\right.$ ); (e) dry-deposition flux of particulate $\mathrm{NO}_{3}{ }^{-}$. Wet-deposition flux data were provided by the NADP/NTN network, and ambient concentrations for the calculation of the dry-deposition fluxes were provided by the NDDN/CASTNet network. See Data and methods: Statistical treatment and Drydeposition measurements for explanation of statistical interpolation procedure and for an explanation of how dry-deposition fluxes were calculated. The peak value on each color bar represents the 95 th percentile for each chemical species. The data and mapped fluxes are available online (Holland et al. 2004).

In Europe a different collection of chemical species was measured extensively enough to make spatial interpolations: $\mathrm{NO}_{2}(\mathrm{~g})$, particulate ammonium, and the sum of nitric acid and particulate nitrate $\left(\mathrm{HNO}_{3}(\mathrm{~g})+\right.$ particulate $\mathrm{NO}_{3}{ }^{-}$). All attempts at separating the summed group of $\mathrm{HNO}_{3}+$ particulate nitrate further, including methodologically (Hjellbrekke et al. 1997) and statistically based on $\mathrm{SO}_{4}{ }^{2-}$ or $\mathrm{NH}_{4}{ }^{+}$concentrations, were unsuccessful (Langford et al. 1992). As mentioned above, we calculated two deposition velocities for the summed species, one assuming that the total quantity was $\mathrm{HNO}_{3}(\mathrm{~g})$, and the other assuming that the total quantity was particulate $\mathrm{NO}_{3}{ }^{-}$. Thus, the $\mathrm{HNO}_{3}$ (g) flux and particulate $\mathrm{NO}_{3}{ }^{-}$fluxes presented represent the upper and lower limit, respectively, of the expected flux (Figs. 5d and e). Among the chemical species measured in Europe, the $\mathrm{HNO}_{3}$ (g) flux was the greatest, with peak deposition rates of $>11 \mathrm{~kg}$ $\mathrm{N} \cdot \mathrm{ha}^{-1} \cdot \mathrm{y}^{-1}$ and an average deposition rate of $2.34 \mathrm{~kg}$ $\mathrm{N} \cdot \mathrm{ha}^{-1} \cdot \mathrm{y}^{-1}$ (Fig. 5e). The particulate $\mathrm{NO}_{3}{ }^{-}$deposition velocity applied to the measured $\mathrm{HNO}_{3}+$ particulate $\mathrm{NO}_{3}{ }^{-}$concentration produced smaller fluxes, with peak deposition rates of $3.1 \mathrm{~kg} \mathrm{~N} \cdot \mathrm{ha}^{-1} \cdot \mathrm{yr}^{-1}$ and mean deposition rates of $0.58 \mathrm{~kg} \mathrm{~N} \cdot \mathrm{ha}^{-1} \cdot \mathrm{yr}^{-1}$ (Fig. 5d). The estimated $\mathrm{NO}_{2}$ dry-deposition flux was higher with peak deposition rates $>11.2 \mathrm{~kg} \mathrm{~N} \cdot \mathrm{ha}^{-1} \cdot \mathrm{yr}^{-1}$ and mean deposition rates of $1.3 \mathrm{~kg} \mathrm{~N} \cdot \mathrm{ha}^{-1} \cdot \mathrm{yr}^{-1}$ (Fig. 5f). For Europe the particulate $\mathrm{NH}_{4}{ }^{+}$flux was more than twice that estimated for the United States, with peak deposition rates of almost $1.9 \mathrm{~kg} \mathrm{~N} \cdot \mathrm{ha}^{-1} \cdot \mathrm{yr}^{-1}$ and average deposition rates of $0.34 \mathrm{~kg} \mathrm{~N} \cdot \mathrm{ha}^{-1} \cdot \mathrm{yr}^{-1}$ (Fig. 5c).

The patterns of dry deposition for all species are driven by the calculated $V_{\mathrm{d}}$ together with the atmospheric concentrations (Eqs. 3 and 4). The maps of the calculated deposition velocities for the two regions are provided in Figs. 6 and 7. For both regions, the $\mathrm{HNO}_{3}$ (g) $V_{\mathrm{d}}$ 's fell within the wide range of measured $V_{\mathrm{d}}$ 's (Table 3). Many of $V_{\mathrm{d}}$ 's calculated for particulate $\mathrm{NH}_{4}{ }^{+}$ and $\mathrm{NO}_{3}{ }^{-}$fell at the upper end of the range or above the range of compiled estimates (Table 3). The $V_{\mathrm{d}}$ 's calculated for $\mathrm{NO}_{2}$ were at the upper end of the range reported in Hanson and Lindberg (1991) and above many of the other compiled estimates. We used the Weseley (1989) method for estimating the $\mathrm{NO}_{2} V_{\mathrm{d}}$, and this does not adequately account for the leave uptake and release and so may have resulted in an overestimate of the deposition velocity (Lerdau et al. 2000).

Estimated dry-deposition fluxes lack the spatial coherence of the wet-deposition fluxes over both conti- 

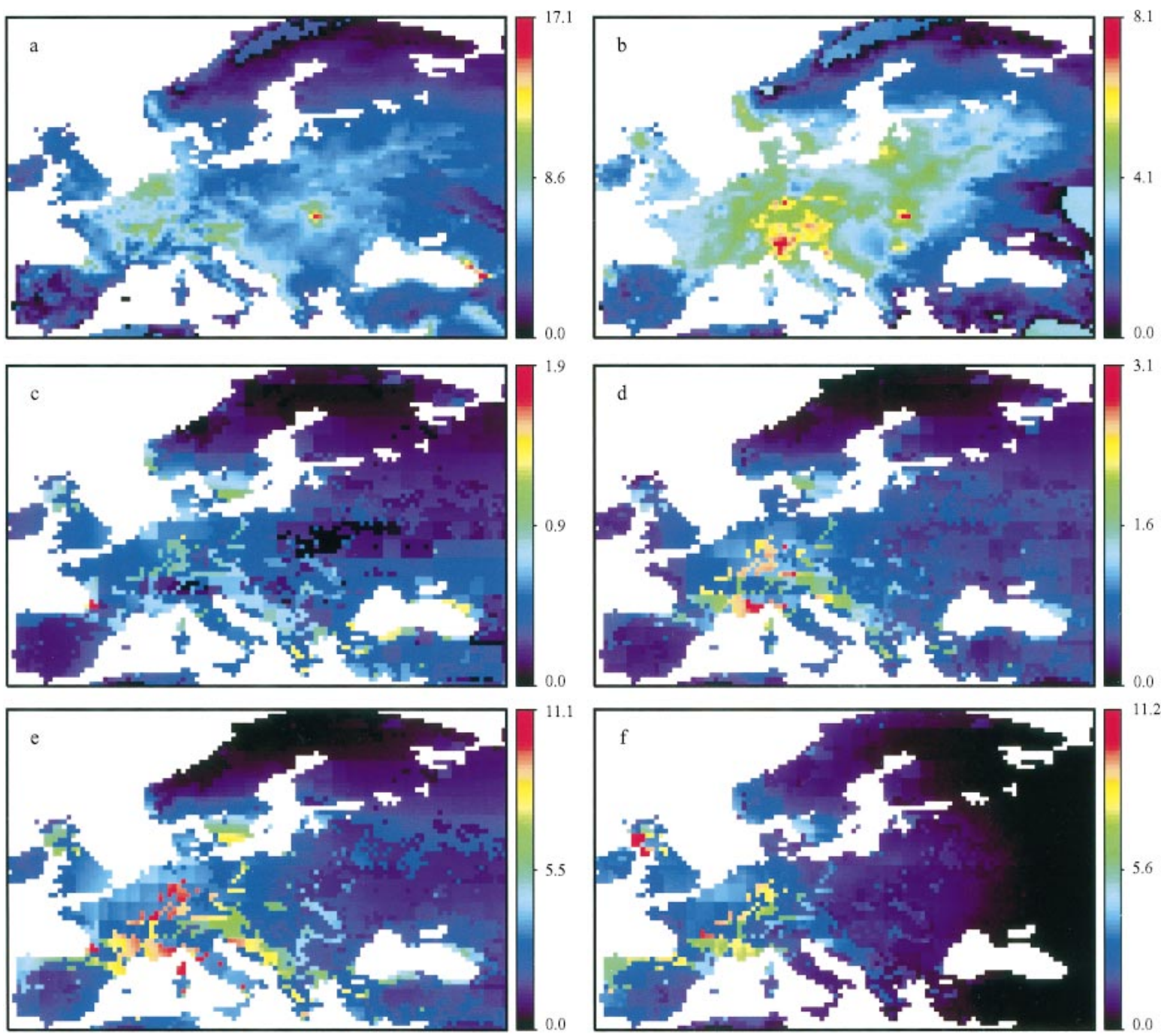

FIG. 5. Spatial distribution of the $\mathrm{N}$ deposition flux estimated for each of the individual $\mathrm{N}$ species measured (kg N/ha) for Europe: (a) wet deposition flux of $\mathrm{NH}_{4}{ }^{+}$(aq); (b) wet-deposition flux of $\mathrm{NO}_{3}{ }^{-}$(aq); (c) dry-deposition flux of particulate $\mathrm{NH}_{4}{ }^{+}$; (d) dry-deposition flux of particulate $\mathrm{NO}_{3}^{-}$; (e) dry-deposition flux of gaseous $\mathrm{HNO}_{3}$ (g); (f) dry-deposition flux of gaseous $\mathrm{NO}_{2}(\mathrm{~g})$. The fluxes of $\mathrm{HNO}_{3}$ and particulate $\mathrm{NO}_{3}^{-}$are representative of the spatial patterns of deposition for each of the species, but the magnitudes of the fluxes are likely overestimated because some chemical species with different deposition velocities were reported as a sum (see Data and methods). Both the wet-deposition data and the ambient concentrations used to calculate the dry-deposition fluxes were provided by the EMEP network. Dry-deposition fluxes were calculated by multiplying the interpolated concentrations by model-estimated deposition velocities. See Data and methods: Dry-deposition measurements for explanation of statistical interpolation procedure and for an explanation of how drydeposition fluxes were calculated. The peak value on each color bar represents the $95 \%$ percentile for each chemical species. The data and mapped fluxes are available online (Holland et al. 2004).

nents. The flux was calculated as a product of spatially interpolated concentrations and the deposition velocity calculated for each grid cell, based on meteorological data and land cover (Figs. 6 and 7). The deposition velocities and thus the underlying land cover had substantial impact on the overall pattern of the dry-deposition fluxes with discrete land-cover boundaries rather than natural spatial variability associated with natural ecotones (Fig. 6 and 7). The dependence on land cover was emphasized when we implemented the increased $V_{\mathrm{d}}$ for particulate fluxes suggested by Jonas and Heinemann (1995) (Table 4). Overall, the increased $V_{\mathrm{d}}$ 's for particulate $\mathrm{NH}_{4}{ }^{+}$onto deciduous, coniferous, and mixed forests increased the spatially integrated deposition by between 3.4- and 5.7-fold. The increase was greater in the United States compared to Europe because of their greater spatial extent of coniferous forests and the associated higher $V_{\mathrm{d}}$. The different drydeposition modeling approaches yield substantially different estimates of fluxes, underscoring the need for regional dry-deposition models that have been extensively compared to the growing number of direct flux 
TABle 3. Comparison of deposition velocities $V_{\mathrm{d}}$ estimated in this study with modeled and measured deposition velocities for reactive $\mathrm{N}$ gases.

\begin{tabular}{|c|c|c|c|c|c|c|}
\hline \multirow[b]{2}{*}{ Reference } & \multirow[b]{2}{*}{$\begin{array}{l}\text { Estimation } \\
\text { technique }\end{array}$} & \multicolumn{5}{|c|}{$V_{\mathrm{d}}(\mathrm{cm} / \mathrm{s})$} \\
\hline & & $\mathrm{HNO}_{3}(\mathrm{~g})$ & $\mathrm{NO}_{\mathrm{y}}$ & $\mathrm{NO}_{2}(\mathrm{~g})$ & $\begin{array}{l}\text { Particulate } \\
\mathrm{NO}_{3}^{-}\end{array}$ & $\begin{array}{l}\text { Particulate } \\
\mathrm{NH}_{4}^{+}\end{array}$ \\
\hline This study & modeled & & & & & \\
\hline Europe average & & 1.36 & $\cdots$ & 0.34 & 0.35 & 0.08 \\
\hline U.S. average & & 1.54 & $\ldots$ & $\ldots$ & 0.27 & 0.05 \\
\hline \multirow[t]{4}{*}{ Baldocchi (1985) } & measured & $2-5$ & $\ldots$ & $\ldots$ & $\ldots$ & $\ldots$ \\
\hline & big-leaf model & $2-4.3$ & $\cdots$ & $\ldots$ & $\cdots$ & $\cdots$ \\
\hline & Eulerian model & $2.2-4$ & $\cdots$ & $\ldots$ & $\cdots$ & $\ldots$ \\
\hline & Lagrangian model & $2.8-3.8$ & $\ldots$ & $\ldots$ & $\ldots$ & $\ldots$ \\
\hline $\begin{array}{l}\text { Bengtsson et al. } \\
\text { (1982) }\end{array}$ & measured & $\ldots$ & $\cdots$ & $\begin{array}{l}0.17-0.43 \\
\text { day } \\
0.07-0.2 \\
\text { night }\end{array}$ & $\cdots$ & $\cdots$ \\
\hline \multirow[t]{2}{*}{$\begin{array}{l}\text { Brook et al. } \\
\quad(1996)\end{array}$} & $\begin{array}{l}\text { modeled, LUM } \\
\text { model }\end{array}$ & $0.97-2.81$ & $\cdots$ & $\cdots$ & $\cdots$ & $\cdots$ \\
\hline & $\begin{array}{l}\text { modeled, NOON } \\
\text { model }\end{array}$ & $1.60-1.91$ & $\cdots$ & $\cdots$ & $\cdots$ & $\cdots$ \\
\hline $\begin{array}{l}\text { Brook et al. } \\
\text { (1997) }\end{array}$ & three models & $1.55-3.49$ & $\cdots$ & $\cdots$ & $\cdots$ & $\cdots$ \\
\hline $\begin{array}{l}\text { Duyzer et al. } \\
\text { (1997) }\end{array}$ & gradient measurement & $\cdots$ & $\cdots$ & $\cdots$ & $\cdots$ & 0.18 \\
\hline Erisman (1994) & gradient measurement & $\ldots$ & $\ldots$ & $0.1-0.4$ & $\ldots$ & $\ldots$ \\
\hline Erisman (1997) & gradient method & $\ldots$ & $\ldots$ & $\ldots$ & $1-2$ & $1-2$ \\
\hline $\begin{array}{l}\text { Fowler et al. } \\
\qquad(1989) \dagger\end{array}$ & measured & $0.52-5.0$ & $\cdots$ & $\cdots$ & $\cdots$ & $\cdots$ \\
\hline $\begin{array}{l}\text { Ganzeveld and Le- } \\
\text { lieveld (1995) }\end{array}$ & modeled & $0.4-7.5$ & $\cdots$ & $0.18-0.33$ & $\cdots$ & $\cdots$ \\
\hline \multirow[t]{2}{*}{$\begin{array}{l}\text { Hanson and Lind- } \\
\text { berg (1991) }\end{array}$} & $\begin{array}{l}\text { summary of measure- } \\
\text { ments and some } \\
\text { models }\end{array}$ & $0.03-26$ & $\cdots$ & $0.1-2.8$ day & $0.1-3.7$ & $0.01-1.3$ \\
\hline & & & & $\begin{array}{c}0.07-0.42 \\
\text { night }\end{array}$ & & \\
\hline $\begin{array}{l}\text { Johannsson et al. } \\
\text { (1987) }\end{array}$ & $\begin{array}{l}\text { branch chamber mea- } \\
\text { surements }\end{array}$ & $\cdots$ & $\cdots$ & $\begin{array}{c}0.1-0.2 \\
\text { day } \$ \\
0.05-0.2 \\
\text { night }\end{array}$ & $\cdots$ & $\cdots$ \\
\hline $\begin{array}{l}\text { Lefer (1997), Le- } \\
\text { fer et al. (1999), } \\
\text { and Lefer and } \\
\text { Talbot }(2001)\end{array}$ & $\begin{array}{l}\text { gradient measure- } \\
\text { ment, and referenc- } \\
\text { es therein }\end{array}$ & $1-6$ & $\cdots$ & $\cdots$ & $0.02-0.4$ & $0.02-0.4$ \\
\hline $\begin{array}{l}\text { Lovett and Lind- } \\
\text { bergh (1993) }\end{array}$ & modeled & $1.3-6$ & $\cdots$ & $\cdots$ & $0.2-0.4$ & $0.2-0.4$ \\
\hline Lovett (1994) & $\begin{array}{l}\text { summary of models } \\
\text { and measurements }\end{array}$ & $1-5$ & $\cdots$ & $\begin{array}{l}0.1-0.5 \text { for } \\
\text { open sto- } \\
\text { mata }\end{array}$ & $\cdots$ & $\cdots$ \\
\hline $\begin{array}{l}\text { Meyers et al. } \\
\quad(1998)\end{array}$ & $\begin{array}{l}\text { modified Bowen ratio } \\
\text { modeled }\end{array}$ & $\begin{array}{l}1-6 \\
1-4.2\end{array}$ & $\begin{array}{l}\cdots \\
\cdots\end{array}$ & $\begin{array}{l}\cdots \\
\ldots\end{array}$ & $\begin{array}{l}\cdots \\
\cdots\end{array}$ & $\begin{array}{l}\cdots \\
\cdots\end{array}$ \\
\hline \multirow[t]{2}{*}{ Müller et al. (1993) } & modified Bowen ratio & 2.2 & $\cdots$ & $\cdots$ & $\cdots$ & $0.2-7$ \\
\hline & measured & $0.6-5.0$ & $\cdots$ & $\cdots$ & $\cdots$ & $\cdots$ \\
\hline $\begin{array}{l}\text { Munger et al. } \\
\text { (1996) }\end{array}$ & eddy covariance & $\ldots$ & $1.5-2$ day & $\cdots$ & $\cdots$ & $\cdots$ \\
\hline $\begin{array}{l}\text { Peters and Bruck- } \\
\text { er-Schatt (1995) }\end{array}$ & modeled & 11 & $\begin{array}{l}0.5 \text { night } \\
\quad \ldots\end{array}$ & $\cdots$ & 1.85 & 0.47 \\
\hline $\begin{array}{l}\text { Rondón et al. } \\
\text { (1993) }\end{array}$ & $\begin{array}{l}\text { branch chamber mea- } \\
\text { surements }\end{array}$ & $\cdots$ & $\cdots$ & $\begin{array}{l}0.08-0.21 \\
\text { day } \\
0.03-0.08 \\
\text { night }\end{array}$ & $\cdots$ & $\cdots$ \\
\hline \multirow{2}{*}{$\begin{array}{l}\text { Ruijgrok et al. } \\
\text { (1994) }\end{array}$} & foliar extraction & $\ldots$ & $\ldots$ & $\ldots$ & $0.13-0.43$ & $\ldots$ \\
\hline & $\begin{array}{l}\text { surrogate surface } \\
\text { throughfall }\end{array}$ & $\begin{array}{l}\cdots \\
\cdots\end{array}$ & $\begin{array}{l}\cdots \\
\cdots\end{array}$ & $\begin{array}{l}\cdots \\
\ldots\end{array}$ & $\begin{array}{l}0.13-0.69 \\
0.33-2.25\end{array}$ & $\begin{array}{l}\cdots \\
\cdots\end{array}$ \\
\hline \multirow{2}{*}{$\begin{array}{l}\text { Ruijgrok et al. } \\
\text { (1997) }\end{array}$} & simplified model & $\ldots$ & $\ldots$ & $\ldots$ & $1.47 \pm 1.43 \S$ & $1.13 \pm 1.00 \S$ \\
\hline & $\begin{array}{l}\text { filter pack measure- } \\
\text { ment }\end{array}$ & $\cdots$ & $\cdots$ & $\cdots$ & $1.2 \pm 1.1 \S$ & $\ldots$ \\
\hline $\begin{array}{l}\text { Sirois and Barrie } \\
\text { (1988) }\end{array}$ & & $1.11-2.94$ & $\cdots$ & $0.10-0.23$ & $0.35-0.65$ & $\cdots$ \\
\hline
\end{tabular}


TABLE 3. Continued.

\begin{tabular}{|c|c|c|c|c|c|c|}
\hline \multirow[b]{2}{*}{ Reference } & \multirow[b]{2}{*}{$\begin{array}{l}\text { Estimation } \\
\text { technique }\end{array}$} & \multicolumn{5}{|c|}{$V_{\mathrm{d}}(\mathrm{cm} / \mathrm{s})$} \\
\hline & & $\mathrm{HNO}_{3}(\mathrm{~g})$ & $\mathrm{NO}_{\mathrm{y}}$ & $\mathrm{NO}_{2}(\mathrm{~g})$ & $\begin{array}{l}\text { Particulate } \\
\mathrm{NO}_{3}^{-}\end{array}$ & $\begin{array}{l}\text { Particulate } \\
\mathrm{NH}_{4}^{+}\end{array}$ \\
\hline \multirow[t]{2}{*}{$\begin{array}{l}\text { Wyers and Duyzer } \\
\text { (1997) }\end{array}$} & $\begin{array}{l}\text { Slinn et al. (1992) } \\
\text { model } \|\end{array}$ & $\ldots$ & $\ldots$ & $\ldots$ & $1.76 \pm 2.04 \S$ & $1.22 \pm 1.02 \S$ \\
\hline & gradient model & $\cdots$ & $\cdots$ & $\cdots$ & 1.1 & $\cdots$ \\
\hline
\end{tabular}
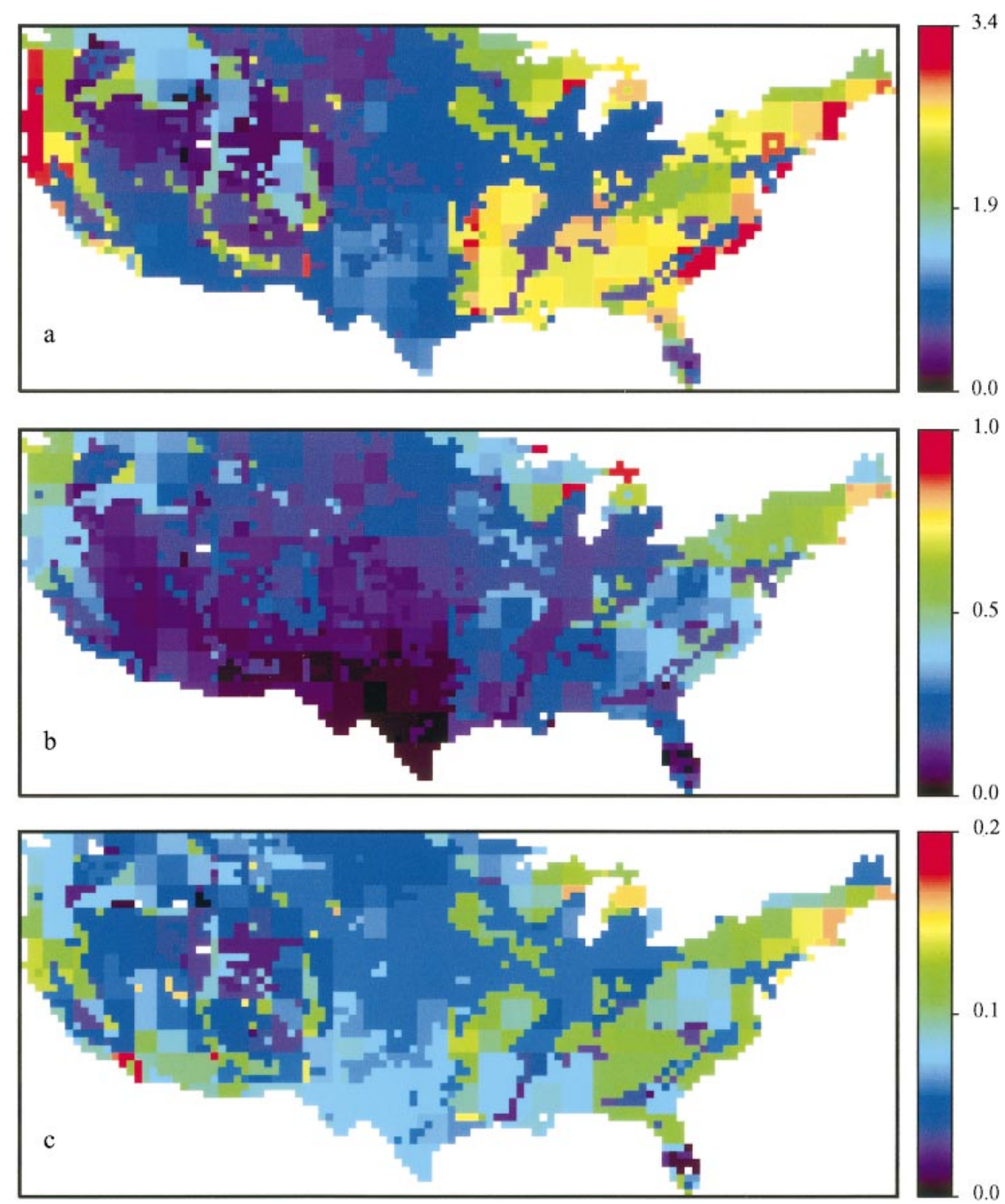

FIG. 6. Spatial distribution of the calculated deposition velocities $\left(V_{\mathrm{d}} ; \mathrm{cm} / \mathrm{s}\right)$ for each of the gases and aerosols considered for the United States: (a) $\mathrm{HNO}_{3}$ (g), (b) particulate $\mathrm{NO}_{3}^{-}$, and (c) particulate $\mathrm{NH}_{4}{ }^{+}$. 

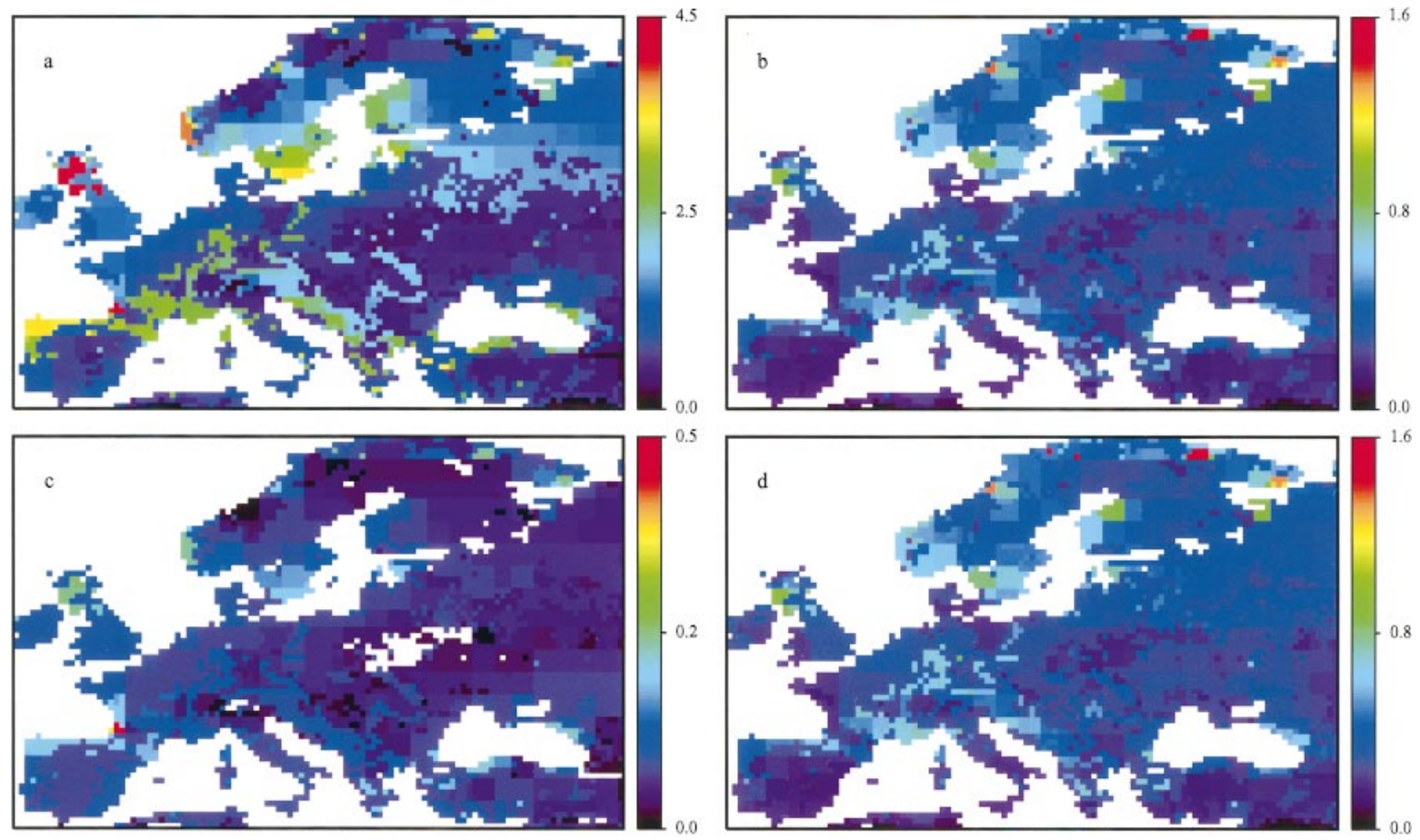

FIG. 7. Spatial distribution of the calculated deposition velocities $\left(V_{\mathrm{d}} ; \mathrm{cm} / \mathrm{s}\right)$ for each of the gases and aerosols considered for Europe: (a) $\mathrm{HNO}_{3}$ (g), (b) particulate $\mathrm{NO}_{3}{ }^{-}$, (c) particulate $\mathrm{NH}_{4}{ }^{+}$, and (d) $\mathrm{NO}_{2}$ (g).

measurements of many of these species (Weseley and Hicks 1999).

\section{Uncertainties, caveats, and sensitivities}

The maps of $\mathrm{N}$ deposition presented highlight a number of issues concerning our understanding of $\mathrm{N}$-deposition. First, what is $\mathrm{N}$ deposition? The summary $\mathrm{N}$ deposition maps presented in Fig. 8 represent the sums of different quantities and are incomplete. The maps for the United States and Europe are comparable for the wet-deposition components $\mathrm{NH}_{4}{ }^{+}$and $\mathrm{NO}_{3}{ }^{-}$, but not for dry deposition. Important constituents of both wet and dry deposition have been neglected in the measurements networks in both the United States and Europe, most notably wet and dry deposition of oxidized and reduced organic nitrogen and $\mathrm{NH}_{3}$ exchange (Langford et al. 1992, Neff et al. 2002). First, $\mathrm{NO}_{2}$ (g) concentrations were measured only in Europe. Critical evaluation of the estimated $\mathrm{NO}_{2}$ deposition is required because of the balance between leaf uptake and release of $\mathrm{NO}_{2}$ (Lerdau et al. 2000). Second, there are substantial differences in sampling density and location between the United States and Europe. Third, the network should include a series of sites where complete $\mathrm{N}$-deposition fluxes, including $\mathrm{NH}_{3}$, particulate $\mathrm{N}$, and organic-N concentrations and exchanges are measured (Munger et al. 1996, 1998, Bouwman et al. 1997, Pryor et al. 2000, Neff et al. 2002).

Estimates of dry-deposition fluxes are less robust than estimates of wet-deposition fluxes despite simi- larities in the magnitude of the two types of fluxes (Figs. 3-5). In Europe, only 115 sites were used to estimate the spatial distribution of aqueous $\mathrm{N}$ deposition over an area $15 \%$ bigger than the size of the conterminous United States. The United States has 237 sites (used in this analysis) for the measurement of wet deposition (Fig. 2). Only 70 of the European sites measured deposition for more than five years. The numbers of samples used to extrapolate dry deposition over the United States were even smaller, at 68 sites, with only

TABLE 4. Comparison of dry deposition onto different biome types using the Weseley method (Weseley et al. 1985, Weseley 1988,1980$)$ and the modified deposition velocity measured by Jonas and Heinemann (1985).

\begin{tabular}{lrc}
\hline \hline & \multicolumn{2}{c}{$\begin{array}{c}\text { Particulate } \mathrm{NH}_{4}{ }^{+} \text {deposition } \\
(\mathrm{Gg} \mathrm{N} / \mathrm{yr})\end{array}$} \\
\cline { 2 - 3 } \multicolumn{1}{c}{ Biome } & Weseley & $\begin{array}{c}\text { Jonas and } \\
\text { Heinemann }\end{array}$ \\
\hline Conterminous United States & \\
$\quad$ Deciduous & 7.64 & 41.69 \\
Coniferous & 20.93 & 113.90 \\
Mixed & 22.01 & 125.40 \\
Europe & & \\
Deciduous & 5.46 & 18.39 \\
Coniferous & 17.87 & 74.76 \\
Mixed & 6.97 & 31.12 \\
\hline
\end{tabular}

Note: According to Jones and Heinemann (1985: Table 2), the average deposition velocity $\left(V_{\mathrm{d}}\right)$ ratios are: coniferous forest : grass, 10.4; deciduous forest : grass, 6.7 ; and mixed forest : grass, 8.6. 

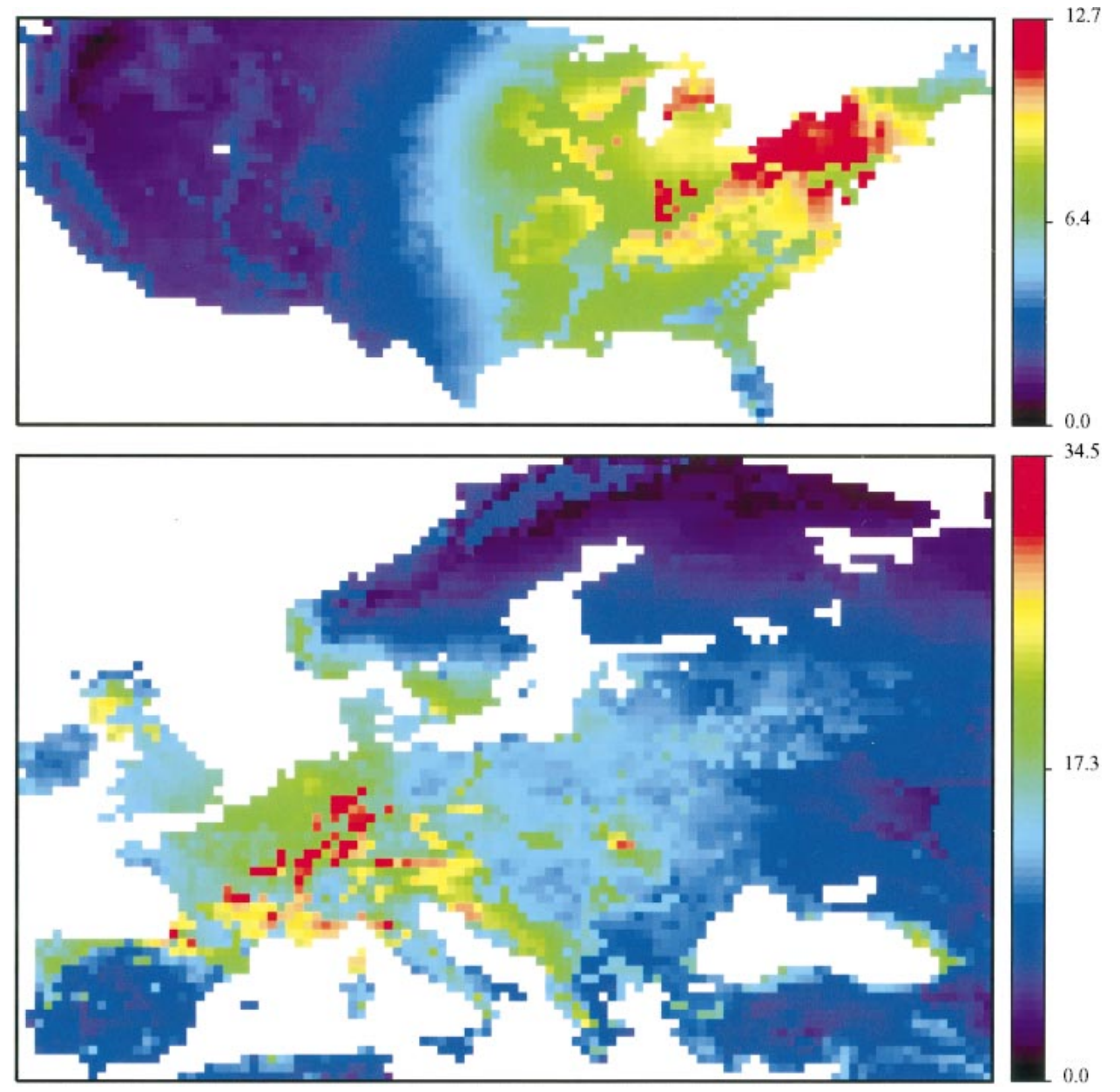

FIG. 8. Estimated $\mathrm{N}$ deposition fluxes summed and integrated over the conterminous United States (top) and Western Europe (bottom). The $\mathrm{N}$ species considered for Europe were wet deposition of $\mathrm{NH}_{4}{ }^{+}-\mathrm{N}$ and $\mathrm{NO}_{3}{ }^{-}-\mathrm{N}$, and dry deposition of $\mathrm{HNO}_{3}-\mathrm{N}(\mathrm{g})$ (using the $V_{\mathrm{d}}$ for $\left.\mathrm{HNO}_{3}\right), \mathrm{NO}_{2}(\mathrm{~g})$, and particulate $\mathrm{NH}_{4}{ }^{+}$. The area of the conterminous United States is 31.01 $\times 10^{6} \mathrm{~km}^{2}$ compared to $35.7 \times 10^{6} \mathrm{~km}^{2}$ in continental Western Europe (excluding some of the small islands of the Norwegian archipelago and portions of Eastern Europe outside the measurement network). The mapped fluxes are available online (Holland 2004).

four years of data for many of the sites. Consequently, the estimated fluxes are uncertain to a degree that is difficult to quantify, but uncertainty associated with interpolation alone ranges from $12 \%$ to $>100 \%$ (based on the estimated Kriging variance). Based on our crossvalidation analyses of wet- and dry-deposition fluxes for the conterminus United States, the squared correlation coefficients $\left(r^{2}\right)$ for wet and dry deposition were 0.93 and 0.48 , respectively. This difference in the uncertainties of the estimates must be kept in mind when evaluating the regional $\mathrm{N}$ budgets presented below. A comprehensive comparison of dry-deposition model estimates and direct flux measurements is called for (Sutton et al. 1993, Munger et al. 1998, Lefer et al. 1999, Pryor et al. 2000, Holland and Carroll 2003).

Within the United States, the practice of locating sites at remote locations far from sources undersamples deposition. The lifetime of $\mathrm{NO}_{x}$ and $\mathrm{NO}_{y}$ in urban and power-plant plumes is estimated to be between 2.80 to $4.2 \mathrm{~h}$ for $\mathrm{NO}_{x}$ and 7.0 to $7.7 \mathrm{~h}$ for $\mathrm{NO}_{y}$. These lifetimes with the corresponding relatively short transport distances in the boundary layer and lower troposphere, the significant nonlinearities in the $\mathrm{NO}_{x} /$ ozone chemistry, the large uncertainties in dry deposition, and the remote location of the NADP sampling stations argue for expanding the NADP, NDDN, CASTnet networks to include urban influences (Nunnermaker et al. 2000, Ryerson et al. 2001, Kleinman et al. 2002). Measurement of deposition in precipitation is a relatively inexpensive means of monitoring the impact and extent of human activities on air chemistry, but it is a mission beyond the original deposition network objective of measuring acidic deposition and its impact on remote areas. To accomplish these expanded objectives, and to provide accurate measurements of reactive $\mathrm{N}$ deposition for terrestrial and atmospheric studies, the 
TABle 5. Budget of estimated $\mathrm{N}$ emissions and deposition for the conterminous United States (units are teragrams of $\mathrm{N}$ per year).

\begin{tabular}{|c|c|c|c|}
\hline Emissions & $\mathrm{NO}_{x}$ & $\mathrm{NH}_{3}$ & $\mathrm{NO}_{x}+\mathrm{NH}_{3}$ \\
\hline Estimated emissions $\dagger$ & $6.24-6.35 \ddagger$ & $3.6-5.2 \S$ & $9.84-11.55$ \\
\hline Deposition & $\mathrm{NO}_{y} \|$ & $\mathrm{NH}_{x} \mathrm{II}$ & $\mathrm{NO}_{y}+\mathrm{NH}_{x}$ \\
\hline \multicolumn{4}{|l|}{ Integrated deposition } \\
\hline Wet deposition fluxes & 1.28 & 1.08 & 2.36 \\
\hline \multicolumn{4}{|l|}{ Dry deposition fluxes } \\
\hline Particulate $\mathrm{NO}_{3}$ & 1.20 & & \\
\hline $\begin{array}{l}\text { Particulate } \mathrm{NH}_{4}^{+} \\
\sum \text { Dry deposition fluxes }\end{array}$ & & $0.18-0.98$ & $138-2.18$ \\
\hline Total wet + dry & 2.48 & $1.26-2.06$ & $3.74-4.54$ \\
\hline Imbalance & 3.76 to 3.87 & 1.54 to 3.94 & 5.30 to 7.81 \\
\hline
\end{tabular}

$\dagger$ See Results and discussion for discussion of emission estimates.

\$ Sources: Benkovitz et al. (1996) from NAPAP inventory by Saeger et al. (1989); U.S. EPA national trends estimated for fossil-fuel estimates only (1978-1994 time period), EPA-454/R-97011.

§ Sources: Dentener and Crutzen (1994) and Bouwman et al. 1997 (estimated for all of North America).

$\| \mathrm{NO}_{y}$ includes measured wet deposition of $\mathrm{NO}_{3}{ }^{-}$and dry deposition of $\mathrm{HNO}_{3}$ (g) and particulate $\mathrm{NO}_{3}{ }^{-}$.

II $\mathrm{NH}_{x}$ includes wet deposition of $\mathrm{NH}_{4}^{+}$and dry deposition of particulate $\mathrm{NH}_{4}^{+}$, but it does not include dry deposition of $\mathrm{NH}_{3}$. The range is determined by the different approaches to calculating particulate deposition, see Table 4 and Results and discussion: Dry-deposition fluxes.

measurements, methods, spatial distribution, and chemical species sampled requires reevaluation.

Within Western Europe there are hundreds of sites where $\mathrm{N}$ deposition in precipitation is measured but not reported to the European Monitoring and Evaluation Program (EMEP). For example, a compilation of $\mathrm{NH}_{4}^{+}$ and $\mathrm{NO}_{3}{ }^{-}$wet-deposition data for 1989 included 750 stations, more than six times the number of stations providing data to EMEP (van Leeuwen et al. 1995, 1996). However, the majority of the additional stations were located in areas that were already sampled, rather than filling in the spatial gaps in the countries with few measurement stations. The requirement that EMEP stations report data daily requires tremendous person power and resources. Not having the data available in a coordinated way is a waste of public resources.

For both regions, the estimated $\mathrm{N}$ deposition did not balance estimated emissions (Tables 5 and 6 ). The imbalance in emission and deposition for the two regions has several likely explanations. First, there may be transport of $\mathrm{N}$ deposition into or out of the region. The United States may be exporting significant quantities of $\mathrm{N}$ offshore for deposit downwind onto the North Atlantic or Europe (Galloway et al. 1996, Prospero et al. 1996). The pattern of greater deposition along the U.S. Eastern seaboard is consistent with this idea. Second, N emissions may be underestimated. Fossil-fuel emissions, which are quantified with the most confidence, carry an estimated uncertainty of $\pm 30 \%$ (Benkovitz et al. 1996). Estimates of natural emissions carry a much greater uncertainty and can exceed $100 \%$, but natural emissions are a relatively small contributor to the reactive- $\mathrm{N}$ budgets outside of the tropics (Lamarque et al. 1995, Bouwman et al. 1997, Lee et al. 1997). A third explanation is that Ndeposition budgets are incomplete for both the United
States and Europe. In both networks, the deposition of organic nitrogen and exchanges of $\mathrm{NH}_{3}$ are not measured, but these fluxes have been shown to be important (Langford et al. 1992, Bouwman et al. 1997, Neff et al. 2002). The European measurements represent a more complete estimation of the suite of $\mathrm{N}$ species involved, but both networks fall short. Finally, the networks are inadequate to measure the spatial distribution of $\mathrm{N}$ deposition, especially the influence of urban and power plumes for the reasons discussed above. The countries within Europe that have the greatest emissions have devoted the most effort to deposition measurements, providing a bias towards higher estimates of deposition (Erisman et al. 1994, van Leeuwen et al. 1996). The U.S. network provides a bias towards lower estimates of deposition by sampling only remote areas, and fails to adequately capture the influence of urban emissions and emissions from point sources, despite the 237 measurement sites.

This budgetary analysis highlights the need for adequate sampling and refocusing the efforts of the European and U.S. networks. Key issues include the need for coordination with existing air pollution monitoring efforts, complete sampling of chemical constituents, expansion of the existing network to include urban influences, and comparison with time-varying emission estimates.

\section{CONCLusions}

The analysis presented here represents a framework for producing mapped atmospheric-deposition products for use in studying the changing biospheric-atmospheric cycle of nitrogen. Our confidence in the estimated N-deposition patterns over both continents is, however, limited by irregular and incomplete spatial 
TABLE 6. Budget of estimated $\mathrm{N}$ emissions and deposition for Europe (units are teragrams of $\mathrm{N}$ per year).

\begin{tabular}{lccc}
\hline \hline \multicolumn{1}{c}{ Emissions } & $\mathrm{NO}_{x}$ & $\mathrm{NH}_{3}$ & $\mathrm{NO}_{x}+\mathrm{NH}_{3}$ \\
\hline Estimated emissions $\dagger$ & $6.1 \neq$ & $4.1-5.2 \S$ & $10.2-11.3$ \\
$\quad$ Deposition & $\mathrm{NO}_{y} \|$ & $\mathrm{NH}_{x} \mathrm{I}$ & $\mathrm{NO}_{y}+\mathrm{NH}_{x}$ \\
\hline Deposition fluxes & & & 6.30 \\
$\quad$ Wet deposition fluxes & 2.34 & 3.96 & $0.55-2.27$ \\
Dry deposition fluxes\# & $0.55-2.27$ & & 1.24 \\
$\mathrm{HNO}_{3}+$ particulate $\mathrm{NO}_{3}^{-}$ & 1.24 & $0.33-1.34$ & $0.33-1.34$ \\
$\mathrm{NO}_{2}$ & $1.79-3.52$ & $0.33-1.34$ & $2.12-4.85$ \\
${\mathrm{Particulate} \mathrm{NH}_{4}{ }^{+}}_{\Sigma \text { Dry deposition fluxes }}$ & $4.13-5.85$ & $4.29-5.30$ & $8.42-11.15$ \\
$\quad$ Total wet + dry & 1.97 to 0.25 & -0.10 to 1.20 & -0.15 to 2.88 \\
Imbalance & & & \\
\hline
\end{tabular}

$\dagger$ See Results and discussion for discussion of emissions.

$¥$ Source: Fossil fuel emission estimates are from Corinair project of the Coordination of Information Environmentale and EMEP inventories for 1985 included in Dentener and Crutzen (1994).

$\S$ Sources: Dentener and Crutzen (1994) and Bouwman et al. (1997).

$\| \mathrm{NO}_{y}$ includes measured wet deposition of $\mathrm{NO}_{3}^{-}$, and dry deposition of $\mathrm{NO}_{2}(\mathrm{~g})$ and $\mathrm{HNO}_{3}(\mathrm{~g})$ and particulate $\mathrm{NO}_{3}^{-}$.

II $\mathrm{NH}_{x}$ includes wet deposition of $\mathrm{NH}_{4}{ }^{+}$and dry deposition of particulate $\mathrm{NH}_{4}{ }^{+}$, but it does not include dry deposition of $\mathrm{NH}_{3}$. The range is determined by the different approaches to calculating dry deposition; see Table 4 and Results and discussion: Dry-deposition fluxes.

\# The dry deposition range for $\mathrm{NO}_{y}$ is based on the use of two different deposition velocities ( $V_{\mathrm{d}}$ 's), one for particulate $\mathrm{NO}_{3}{ }^{-}$and one for $\mathrm{HNO}_{3}$. See Results and discussion: Dry-deposition fluxes for further explanation.

sampling, and by the lack of an adequate procedure for estimating dry-deposition velocities of N-containing gases and particulates. For both the United States and Europe, deposition of $\mathrm{NH}_{4}^{+}$in precipitation was the most significant flux of $\mathrm{N}$ observed, but because of the uncertainties associated with determining the dry-deposition fluxes, a strict ranking of the fluxes remains problematic. Despite the large uncertainties, there appear to be large differences in the chemical climates of two major portions of the developed world. Over the United States, only $40 \%$ of the estimated emissions were captured by the deposition measurements. By contrast, in Western Europe deposition measurements captured a much higher proportion of emissions, and some calculations suggested Western Europe received more $\mathrm{N}$ than it emitted, arguing for net $\mathrm{N}$ import to the region (Tables 5 and 6).

The levels of $\mathrm{N}$ being deposited over most of Europe exceed the many estimates of critical loads of between 10-20 kg N.ha-1. $\mathrm{y}^{-1}$. Fewer such severely impacted areas appear in the analysis of the U.S. data. The likelihood that a region will undergo $\mathrm{N}$ saturation depends on the interactions among soil properties, land use, stand age (for forests), climate variation, and the rates and history of $\mathrm{N}$ deposition (Aber et al. 1989, 1993, 1995, 1997, 1998, Ollinger et al. 1993, Aber and Driscoll 1997). Substantial areas of both the United States and Europe have been receiving large quantities of $\mathrm{N}$ for longer than the period of measurement, and therefore must be monitored directly.

The establishment of both the EMEP and NADP/ NTN networks was originally motivated by concern over acid rain and its effects on rural and remote regions, and continuing collection of this valuable set of measurements is essential. After years of acid rain research, we know the problems and how to design an effective sampling network, but the scientific issues have shifted from quantifying acid deposition with emphasis on sulfuric acid deposition to a growing focus on nitrogen deposition and base cations (Hedin et al. 1994, Likens et al. 1996, Aber et al. 1997). The data are essential to address emerging questions such as the quantification of $\mathrm{N}$ deposition fluxes over large areas, the influence of $\mathrm{N}$ deposition on changing species composition in terrestrial and aquatic ecosystems, and large-scale changes in ecosystem biogeochemistry.

\section{ACKNOWLEDGMENTS}

The paper is dedicated to the memory of our revered colleague David Bigelow who believed in the NADP from the day of its inception until the day he died, and whose attention to analytical details helped establish an outstanding measurement network.

We thank Tim Haas for providing his MWRK code and for generous assistance with its use. We also thank Anne-Gunn Hjellbrekke of EMEP, Cathy Copeland and Dave Bigelow of NADP, Ralph Baumgartner and Eric S. Edgerton or CASNet/ NDDN data, and the dedicated station operators in the United States and Europe for making this study possible. James Galloway provided impetus and encouragement. We thank Barry Lefer, John Orlando, David Schimel, Elizabeth Sulzman, and two anonymous reviewers for their thorough and thoughtful criticisms of the manuscript. The research was supported by the National Center for Atmospheric Research, the Max Planck Institute für Biogeochemie, Jena, Germany, the Department of Energy's National Institutes for Global Environmental Change, the National Science Foundation's Methods and Models for Integrated Assessment Program (award number 9793346), and the National Aeronautics and Space Administration. The National Center for Atmospheric Research is operated by the University Corporation for Atmospheric Research under sponsorship of the National Science Foundation. 


\section{Literature Cited}

Aber, J. D., and C. T. Driscoll. 1997. Effects of land use, climate variation and $\mathrm{N}$ deposition on $\mathrm{N}$ cycling and carbon storage in northern hardwood forests. Global Biogeochemical Cycles 11:639-648.

Aber, J. D., A. Magill, R. Boone, J. M. Melillo, P. Steudler, and R. Bowden. 1993. Plant and soil responses to chronic nitrogen additions at the Harvard forest, Massachusetts. Ecological Applications 3:156-166.

Aber, J. D., A. Magill, and R. Hallett. 1995. Forest biogeochemistry and primary production altered by nitrogen saturation. Water, Air, and Soil Pollution 85:1665-1672.

Aber, J. D., W. McDowell, K. Nadelhoffer, A. Magill, G. Bernston, M. Kamakea, S. McNulty, W. Currie, L. Rustad, and I. Fernandez. 1998. Nitrogen saturation in temperate forest ecosystems. BioScience 11:921-934.

Aber, J. D., J. K. Nadlehoffer, P. A. Steudler, and J. M. Melillo. 1989. Nitrogen saturation in northern forest ecosystemshypotheses and implications. BioScience 39:378-386.

Aber, J. D., S. V. Ollinger, and C. T. Driscoll. 1997. Modeling nitrogen saturation in forest ecosystems in response to land use and atmospheric deposition. Ecological Modeling 101: 61-78.

Aerts, R., F. Berendse, and H. de Caluwe. 1990. Competition in healthland along an experimental gradient of nutrient availability. Oikos 57:310.

Albritton, D. A., R. T. Watson, and P. J. Aucamp. 1994. Scientific assessment of ozone depletion: 1994. in C. E. Ennis, editor. Global Ozone Research and Monitoring Project report 37. World Meteorological Organization, Genetic, Switzerland.

Baldocchi, D. B. 1985. On estimating $\mathrm{HNO}_{3}$ deposition to a deciduous frosts with a Lagrangian random-walk model. Pages 1081-1093 in S. E. Schwartz and W. G. N. Slinn, editors. Precipitation scavenging and atmosphere-surface exchange. Volume 2. The Semonin volume, atmosphericsurface exchange processes. Hemisphere Publishing, Washington, D.C., USA.

Bengtsson, C., P. Grenfelts, C. Å. Bostöm, E. Troeng, L. Skärby, ̊. Sjödin, and K. Peterson. 1982. Deposition and uptake of nitrogen oxides in Scots pine needles (Pinus Sylvestris L.), Gothenburg, Sweden. Water and Air Pollution Research, Report IVL-B 647.

Benkovitz, C. M., M. T. Scholtz, J. Pacyna, L. Tarrason, J. Dignon, E. C. Voldner, P. A. Spiro, J. A. Logan, and T. E. Graedel. 1996. Global gridded inventories of anthropogenic emission of sulfur and nitrogen. Journal of Geophysical Research 101:29,239-29,253.

Berendse, F., W. Th. Elberse, and R. H. M. E. Geerts. 1992. Competition and nitrogen loss from plants in grassland ecosystems. Ecology 73:46-53.

Bobbink, R., G. W. Heil, and M. B. A. G. Raeseen. 1992. Atmospheric deposition and canopy exchange processes in heathland ecosystems. Environmental Pollution 75:29-37.

Bouwman, A. F., D. S. Lee, W. A. H. Asman, F. J. Dentener, K. W. Vander Hoek, and J. G. J. Olivier. 1997. A global high-resolution emission inventory for ammonia. Global Biogeochemical Cycles 11:561-588.

Brook, J. R., R. Di-Giovanni, S. Cakmak, and T. P. Meyers. 1997. Estimation of dry deposition velocity using inferential models and site-specific meteorology-uncertainty due to siting of meteorological towers. Atmospheric Environment 31:3,911-3,919.

Brook, J. R., A. Sorois, and J. F. Clarke. 1996. Comparison of dry deposition velocities for $\mathrm{SO}_{2}, \mathrm{HNO}_{3}$, and $\mathrm{SO}^{2-}{ }_{4}$ estimated with two inferential models. Water, Air and Soil Pollution 87:205-218.

CASTNet, (Clean Air Status and Trends Network.).U.S. Environmental Protection Agency. 〈http://www.epa.gov/ castnet $\rangle$.
Chapin, F. S., III, B. H. Walken, R. J. Habbs, D. H. Hooper, J. H. Lawton, O. E. Sala, and D. Tilman. 1997. Biotic control over the functioning of ecosystems. Science 277: 500.

Church, M. R., and C. T. Driscoll. 1997. Nitrogen cycling in forested catchments: a Chapman Conference. Global Biogeochemical Cycles 11(4):613-616.

Cowling, E. B. 1989. Recent changes in chemical climate and related effects on forests in North America and Europe. Ambio 18:167-171.

Cressie, N. 1991. Statistics for spatial data. John Wiley and Sons, New York, New York, USA.

DeFries, R. S., and J. R. G. Townsend. 1995. An initial coarse resolution HDVI-derived global land cover classification. In ISLSCP (International Satellite Land Surface Climatology Project) Initiative 1: global data sets for land-atmosphere models 1987-1988. [CD-ROM]. Goddard Institute for Space Studies, Greenbelt, Maryland, USA.

Dentener, F. J., and P. J. Crutzen. 1994. A three-dimensional model of the global ammonia cycle. Journal of Atmospheric Chemistry 19:331-369.

Dovland, H., and U. Pedersen. 1997. Acid deposition in Europe. Pages 53-68 in D. M. Whelpdale and M. S. Kaiser, editors. Global acid deposition assessment (53-69). World Meteorological Organization, Geneva, Switzerland.

Duyzer, J. H., A. M. M. Bouman, R. M. van Aalst, and H. S. M. A. Diederen. 1997. Assessment of dry deposition fluxes of $\mathrm{NH}_{3}$ and $\mathrm{NH}^{+}{ }_{4}$ over natural terrains. Pages 97106 in W. A. H. Asman and S. M. A. Diedren, editors. EURASAP Symposium, ammonia and acidification. National Institute for Public Health and Environmental Hygiene, Bilthoven, The Netherlands.

Edgerton, E. S., T. F. Lavery, and R. P. Boksleitner. 1992. Preliminary data from the USEPA dry deposition network: 1989. Environmental Pollution 75:45-155.

EMEP (European Monitoring and Evaluation Program). 1995. Data Report. 〈http://emep.int〉

Erisman, J. W., C. Beier, G. Graaijers, and S. Lindberg. 1994. Review of deposition monitoring methods. Tellus 46B:7993.

Erisman, J. W., and G. P. J. Draaijers. 1995. Studies in environmental science 63. Atmospheric deposition in relation to acidification and eutrophication. Elsevier Press, New York, New York, USA.

Erisman, J. W., G. Draaijers, L. Duyzer, P. Hofschreuder, N. van Leeuwen, F. Römer, W. Ruijgrok, P. Wyers, and M. Gallagher. 1997. Particle deposition to forests-summary of results and application. Atmospheric Environment 31:321332.

Galloway, J. N., R. W. Howarth, A. F. Michaels, S. W. Nixan, J. M. Prospero, and F. J. Dentener. 1996. Nitrogen and phosphorus budgets of the North Atlantic Ocean and its watershed. Biogeochemistry 35:3-25.

Galloway, J. S., I. H. Levy, and P. S. Kasibhalta. 1994. Year 2020: consequences of population growth and development on depostion of oxidized nitrogen. Ambio 23:120.

Galloway, J. N., W. H. Schlesinger, H. Levy, II, A. Michaels, and J. L. Schnoor. 1995. Nitrogen fixation: anthropogenic enhancement-environmental response. Global Biogeochemical Cycles 9:235-252.

Ganzeveld, L., and J. Lelieveld. 1995. Dry deposition parameterization in a chemistry general circulation model and its influence on the distribution of reactive trace gases. Journal of Geophysical Research 100D10:20,999-21,012.

Grennfelt, P., and J. N. Galloway. 1997. Effects of acidic deposition. Pages 33-49 in D. M. Whelpdale and M. S. Kaiser, editors. Global acid deposition assessment. Report No. 106. World Meterological Organization, Geneva, Switzerland. 
Haas, T. C. 1990. Kriging and automated variogram modeling within a moving window. Atmospheric Environment 24A: 1759-1769.

Haas, T. C. 1995. Local predictions of spatio-temporal process with an application to wet sulfate deposition. Journal of the American Statistical Association 90:1-11.

Hanson, P. J., and S. E. Lindberg. 1991. Dry deposition of reactive nitrogen compounds: a review of leaf, canopy and non-foliar measurements. Atmospheric Environment 25A: 1,615-1,634.

Hedin, L. O., L. Granat, G. E. Likens, T. A. Buishand, J. N. Galloway, T. J. Butler, and H. Rodhe. 1994. Steep declines in atmospheric base cations in regions of Europe and North America. Nature 367:351-354.

Hedin, L. O., and G. E. Likens. 1996. Atmospheric dust and acid rain. Scientific American 275(December):88-92.

Hicks, B. B., R. P. Hosker, Jr., T. P. Meyers, and J. D. Womack. 1991. Dry deposition inferential measurement techniques. 1. Design and tests of a prototype meteorological and chemical system for determining dry deposition. Atmospheric Environment 25A:2345-2359.

Hjellbrekke, A.-G., J. Schaug, J. E. Hansen, and J. E. Skjelmoen. 1997. EMEP Co-operative Programme for monitoring and evaluation of the long-range transmission of air pollutants in Europe: data report 1995. In Annual summaries: EMEO/CCC Report 4/97. World Meteorological Institute, Geneva, Switzerland.

Holland, E. A., B. H. Braswell, J.-F. Lamarque, A. Townsend, J. M. Sulzman, J.-F. Müller, F. Dentener, G. Brasseur, H. Levy, II, J. E. Penner, and G. Roelofs. 1997. Variations in the predicted spatial distribution of atmospheric nitrogen deposition and their impact on carbon uptake by terrestrial ecosystems. Journal of Geophysical Research 102:15,84915,966 .

Holland, E. A., B. H. Brasswell, J. Sulzman, and J.-F. Lamarque. 2004. Nitrogen deposition for the United States and Western Europe, 1978-1994. [Data set]. Oak Ridge National Laboratory Data Access and Archiving Center, Oak Ridge, Tennessee, USA. 〈http://www.daac.ornl.gov〉.

Holland, E. A., and M. A. Carroll. 2003. Atmospheric chemistry and the bio-atmospheric carbon and nitrogen cycles. Pages 273-294 in J. M. Melillo, C. B. Field, and B. Moldan, editors. Interactions of the major biogeochemical cycles: global change and human impacts. SCOPE Volume 61. Island Press, Washington, D.C., USA.

Holland, E. A., F. J. Dentener, B. H. Braswell, and J. M. Sulzman. 1999. Contemporary and pre-industrial global reactive nitrogen budgets. Biogeochemistry 46:7-43.

Hooper, D. U., and P. M. Vitousek. 1997. The effects of plant composition and diversity on ecosystem processes. Science 277:1302.

Howarth, R. W., et al. 1996. Regional nitrogen budgets and riverine $\mathrm{N} \& \mathrm{P}$ fluxes for the drainages to the North Atlantic Ocean: natural and human influences. Biogeochemistry 35: 75-139.

Jenkinson, D. S., K. Goulding, and D. S. Powlson. 1999. Nitrogen deposition and sequestration. Nature 400:629.

Johannsson, C. 1987. Pine forest: a negligible sink for atmospheric $\mathrm{NO}_{x}$ in rural Sweden. Tellus 39B:426-438.

Jonas, R., and K. Heinemann. 1995. Studies on the dry deposition of aerosol particles on vegetation and plane surfaces. Journal of Aerosol Science 16:463-471.

Kalnay, E., et al. 1996. The NCEP/NCAR 40-year reanalysis project. Bulletin of the American Meteorological Society 3:437-471.

Kittel, T. G. F., N. A. Rosenbloom, T. H. Painter, D. S. Schimel, and VEMAP participants. 1995. The VEMAP integrated database for modeling United States ecosystem/vegetation sensitivity to climate change. Journal of Biogeography 22:857-862.
Kleinman, L. I., P. H. Daum, Y.-N. Lee, L. J. Nunnermacker, S. R. Springston, J. Weinstein-Lloyd, and J. Rudolph. 2002. Ozone production efficiency in an urban area. Journal of Geophysical Research 107(23):4733. (doi:10.1029/2002JD002529).

Lamarque, J. F., G. Brasseur, P. G. Hess, and J.-F. Müller. 1995. Three-dimensional study of the relative contributions of the different nitrogen sources in the troposphere. Journal of Geophysical Research 101:22,955-22,968.

Lamb, D., and V. Bowersox. 2000. The national atmospheric deposition program: an overview. Atmospheric Environment 34:1661-1663.

Langford, A. O., F. C. Fehsenfeld, J. Zachariassen, and D. S. Schimel. 1992. Gaseous ammonia fluxes and background concentrations in terrestrial ecosystems of the United States. Global Biogeochemical Cycles 6:459-483.

Lee, D. S., I. Kohler, E. Grobler, F. Rohrer, R. Sausen, L. Gallardo-Klenner, J. G. J. Olivier, F. J. Dentener, and A. F. Bouwman. 1997. Estimations of global $\mathrm{NO}_{x}$ emissions and their uncertainties. Atmospheric Environment 31:17351749.

Leemans, R., and W. P. Cramer. 1991. The IIASA database for mean monthly values of temperature, precipitation and cloudiness of the global terrestrial grid. International Institute of Applied Systems Analyses, Laxenvurg, Austria.

Lefer, B. L. 1997. The chemistry and dry deposition of atmospheric nitrogen at a rural site in the Northeastern United States, Dissertation. University of New Hampshire, Durham, New Hampshire, USA.

Lefer, B. L., R. W. Talbot, and J. W. Munger. 1999. Nitric acid and ammonia at a rural northeastern U.S. site. Journal of Geophysical Research 104:1645-1661.

Lefer, B. L., R. Talbot, and J. W. Munger. 2001. Aerosol nitrate and ammonium at a northeastern U.S. site. Journal of Geophysical Research 106:20,365-20,378.

Lerdau, M. T., J. W. Munger, and D. J. Jacob. 2000. The $\mathrm{NO}_{2}$ flux conundrum. Science 289:2291-2293.

Likens, G. E., C. T. Driscoll, and D. C. Buso. 1996. Longterm effects of acid rain: response and recovery of a forest ecosystem. Science 272:244-296.

Liu, S. C., D. Kley, M. McFarland, J. D. Mahlman, and H. Levy, II. 1980. On the origin of tropospheric ozone. Journal of Geophysical Research 85:7546-7552.

Liu, S. C., M. Trainer, F. C. Fehsenfeld, D. D. Parrish, E. J. Williams, D. W. Fahey, G. Hübler, and P. C. Murphy. 1987. Ozone production in the rural troposphere and the implications for regional and global ozone distributions. Journal of Geophysical Research 92:4191-4207.

Logan, J. A. 1994. Trends in the vertical distribution of ozone: an analysis of ozonesonde data. Journal of Geophysical Research 99:25,553-25,585.

Lovett, G. M. 1994. Atmospheric deposition of nutrients and pollutants in North America: an ecological perspective. Ecological Applications 4:629-650.

Lovett, G. M., and S. E. Lindbergh. 1993. Atmospheric deposition and canopy interactions of nitrogen in forests. $\mathrm{Ca}$ nadian Journal of Forest Research 23:1,603-1,616.

Lynch, J. A., V. C. Bowersox, and J. W. Grimm. 2000. Changes in sulfate deposition in eastern USA following implementation of Phase 1 of Title IV of the Clean Air Act Amendments of 1990. Atmospheric Environment 34:16651680.

Matson, P. A., W. J. Parton, A. G. Power, and M. J. Swift. 1997. Agricultural intensification and ecosystem properties. Science 277:504-509.

Matthews, E. 1994. Nitrogenous fertilizers: global distribution of consumption and associated emissions of nitrous oxide and ammonia. Global Biogeochemical Cycles 8:411439.

Mayewski, P. A., W. B. Lyons, M. J. Spencer, M. S. Twickler, C. F. Buck, and S. Whitlow. 1990. An ice-core record of 
atmospheric response to anthropogenic sulphate and nitrate. Nature 346:554-556.

Meixner, F. X. 1994. Surface exchange of odd nitrogen oxides. Nova Acta Leopoldina NF 70(288):299-348.

Meyers, T. P., P. Finkelstein, J. Clarke, T. G. Ellestad, and P. F. Sims. 1998. A multilayer model for inferring dry deposition using standard meteorological measurements. Journal of Geophysical Research 103(D17):22,64522,661 .

Müller, H., G. Kramm, F. Meixner, G. J. Dollard, D. Fowler, and M. Possanzini. 1993. Determination of $\mathrm{HNO}_{3}$ dry deposition by modified bowen ratio and aerodynamic profile techniques. Tellus 45B:346-367.

Munger, J. W., S.-M. Fan, P. S. Bakwin, M. L. Goulden, A. H. Goldstein, A. S. Colman, and S. C. Wofsy. 1998. Regional budgets for nitrogen oxides from continental sources: variations of rates for oxidation and deposition with season and distance from source regions. Journal of Geophysical Research 103:8355-8368.

Munger, J. W., S. C. Wofsy, P. S. Bakwin, S. M. Fan, M. L. Goulden, B. C. Daube, and A. H. Goldstein. 1996. Atmospheric deposition of reactive nitrogen oxides and ozone in a temperate deciduous forest and a subarctic woodland. 1. Measurement and mechanisms. Journal of Geophysical Research 101(D7): 12,639-12,657.

Nadelhoffer, K. J., B. A. Emmett, P. Gundersen, O. J. Kjonass, C. J. Koopmans, P. Schleppi, A. Tietema, and R. F. Wright. 1999a. Nitrogen deposition makes a minor contribution to carbon seqestration in temperate forests. Nature 398:145148.

Nadelhoffer, K. J., B. A. Emmett, P. Gundersen, O. J. Kjonass, C. J. Koopmans, P. Schleppi, A. Tietema, and R. F. Wright. $1999 b$. Nitrogen deposition makes a minor contribution to carbon seqestration in temperate forests, reply. Nature 400: 630.

NADP/NTN (National Atmospheric Deposition Program/ National Trends Network). 1979-1994. 〈http://nadp.sws. uiuc.edu $\rangle$.

Neff, J. C., E. A. Holland, F. J. Dentener, W. J. McDowell, and K. M. Russell. 2002. Atmospheric organic nitrogen; implications for the global $\mathrm{N}$ cycle. Biogeochemistry $\mathbf{5 7}$ : 99-136.

Nunnermacker, L. J., L. I. Kleinman, D. Imre, P. H. Daum, Y.-N. Lee, J. H. Lee, S. R. Springston, and L. Newman. 2000. $\mathrm{NO}_{y}$ lifetimes and $\mathrm{O}_{3}$ production efficiency in urban and power plant plumes: analysis of field data. Journal of Geophysical Research 105(D7):9165-9176.

Ollinger, S. V., and J. D. Aber. 2002. The interactive effects of land use, carbon dioxide, ozone, and N deposition. Global Change Biology 8:545-562.

Ollinger, S. V., J. D. Aber, G. M. Lovett, S. E. Millham, R. G. Lathrop, and J. M. Ellis. 1993. A spatial model of atmospheric deposition for the northeastern U.S. Ecological Applications 3:459-472.

Ollinger, S. V., J. A. Aber, and P. B. Reich. 1997. Simulating ozone effects on forest productivity: interactions among leaf-, canopy- and stand-level processes. Ecological Applications 7:1273-1251.

Peters, K., and G. Bruckner-Schatt. 1995. The dry deposition of gaseous and particulate nitrogen compounds to a spruce stand. Water, Air and Soil Pollution 85:2,217-2,222.

Peterson, B. J., and J. M. Melillo. 1985. The potential storage of carbon caused by eutrophication of the biosphere. Tellus Series. B 37:117-127.

Prather, M., et al. 2001. Atmospheric chemistry and greenhouse gases. Contribution of working group 1. Pages 239288. in J. T. Houghton, Y. Ding, D. J. Griggs, M. Noguer, P. J. van der Linden, X. Dai, K. Maskell, and C. A. Johnson, editors. Third annual assessment report of the Intergovern- mental Panel on Climate Change. Cambridge University Press, Cambridge, UK.

Prospero, J. M., K. Barrett, T. Church, F. Dentener, R. A. Duce, J. N. Galloway, H. Levy, II, J. Moody, and P. Quinn. 1996. Atmospheric deposition of nutrients to the North Atlantic Basin. Biogeochemistry 35:27-73.

Pryor, S. C., R. C. Barthelmie, and B. Jensen. 2000. Nitrogen dry deposition at an AmeriFlux site in a hardwood forest in the MidWest. Geophysical Research Letters 26:691-694.

Rondón, A., C. Johannsson, and L. Granat. 1993. Dry deposition of nitrogen dioxide and ozone to coniferous forests. Journal of Geophysical Research 98(D3):5,1595,172 .

Ruijgrok, W., H. Tieben, and P. Eisinga. 1994. The dry deposition of acidifying and alkaline particles on Douglas fir. Report 20159-KES 94-X. KEMA. Arnhem, The Netherlands.

Ruijgrok, W., H. Tieben, and P. Eisinga. 1997. The dry deposition of particles to a forest canopy: a comparision of model and experimental results. Atmospheric Environment 31:399-415.

Ryerson, T. B., et al. 2001. Observations of ozone formation in power plant plumes and implications for ozone control strategies. Science 292:719-721.

Saeger, M., et al. 1989. The 1985 NAPAP emissions inventory (version 2): development of the annual data and modelers' tapes. U.S. Environmental Protection Agency, Research Triangle Park, North Carolina, USA.

Schimel, D. S. 1995. Terrestrial ecosystems and the carbon cycle. Global Change Biology 1:77-91.

Schindler, D. W. 1988. Effects of acid rain on freshwater ecosystems. Science 239:149-157.

Schulze, E. D., editor. 2000. Carbon and nitrogen cycling in European forest ecosystems. Springer-Verlag, New York, New York, USA.

Schulze, E. D., W. De Vries, M. Hauhs, K. Rosén, L. Rasmussen, O.-C. Tann, and J. Nilsson. 1989. Critical loads for nitrogen deposition in forest ecosystems. Water, Air, and Soil Pollution 48:451-456.

Sievering, H. L. 1999. Nitrogen deposition and sequestration. Nature 400:630.

Sirois, A., and L. A. Barrie. 1988. An estimate of the importance of dry deposition as a pathway of acidic substances from the atmosphere to the biosphere in eastern Canada. Tellus 40B:59-80.

Slinn, W. G. N. 1982. Predictions for particle deposition to vegetative surfaces. Atmospheric Environment 16:17851794.

Smil, V. 1997. Global population and the nitrogen cycle. Scientific American 277:76-81.

Stoddard, J. L. 1994. Long-term changes in watershed retention of $\mathrm{N}$ : its causes and aquatic consequences. Pages 223-284 in L. A. Baker, editor. Environmental chemistry of lakes and reservoirs. Advances in Chemistry Series 237. American Chemical Society, Washington, D.C., USA.

Stoddard, J. L., C. T. Driscoll, J. S. Kahl, and J. H. Kellogg. 1998. Can site-specific trends be extrapolated to a region? An acidification example for the northeast. Ecological Applications 8:288-299.

Sutton, M. A., C. E. R. Pitcairn, and D. Fowler. 1993. The exchange of ammonia between the atmosphere and plant communities. Advances in Ecological Research 24:301393.

Tilman, D., J. Knops, D. Wedin, P. Reich, M. Ritchie, and E. Siemann. 1997. The influence of functional diversity and composition on ecosystem processes. Science 277:13001302 .

Townsend, A. R., B. H. Braswell, E. A. Holland, and J. E. Penner. 1996. Spatial and temporal patterns in terrestrial 
carbon storage due to deposition of anthropogenic nitrogen Ecological Applications 6:806-814.

van Leeuwen, E. P., G. P. J. Draaijers, and J. W. Erisman. 1996. Mapping wet deposition of acidifying components and base cations over Europe using measurements. Atmospheric Environment 30:2495-2511.

van Leeuwen, E. P., J. W. Erisman, G. P. J. Draaijers, C. J. M. Potma, and W. A. J. van Pul. 1995. European wet deposition maps based on measureuments. (RIVM report number 722108108006) Research for Man and Environment, Bilthoven, The Netherlands.

Vitousek, P. M., J. D. Aber, R. W. Howarth, G. E. Likens, P. A. Matson, D. W. Schindler, W. H. Schlesinger, and D. G. Tilman. 1997. Human alteration of the global nitrogen cycle: sources and consequences. Ecological Applications 7: 737-750.

Wedin, D. A., and D. Tilman. 1996. Influence of nitrogen loading and species composition on the carbon balance of grasslands. Science 274:1720-1723.

Weseley, M. L. 1988. Improved parameterization for surface resistance to gaseous dry deposition in regional-scale numerical models. EPA/600/3-88/025. U.S. Environmenta
Protection Agency, Research Triangle Park, North Carolina, USA.

Weseley, M. L. 1989. Parameterization of surface resistances to gaseous dry deposition in regional-scale numerical models. Atmospheric Environment 23:1293-1304.

Weseley, M. L., D. R. Cook, R. L. Hart, and R. E. Speer. 1985. Measurement and parameterization of particle sulfur deposition over grass. Journal of Geophysical Research 90: 2131-2143.

Weseley, M. L., and B. B. Hicks. 1999. A review of the current status of knowledge on dry deposition. Atmospheric Environment 34:2261-2282.

Whelpdale, D. M. and M. S. Kaiser. 1997. Global acid deposition assessment. Report number 106. World Meterological Organization, Geneva. Switzerland.

Whelpdale, D. M., P. W. Summers, and E. Sanhueza. 1997. A global overview of atmospheric acid deposition fluxes. Environmental Monitoring and Assessment 48:217-247.

Wyers, G. P., and J. H. Duyzer. 1997. Micrometeorological measurement of the dry deposition flux of sulphate and nitrate aerosols to a coniferous forest. Atmospheric Environment 31:3:333-343. 